\title{
مظاهر الهخراف التشريعي في القوانين الجنائية وأثره في الاستقرار القانوني
}

\author{
محمد رشيد حسن \\ قسم القانون ، كلية القانون و السياسة ،جامعة التنمية البشرية، السليانية، اقليم كردستان ، العراق
}

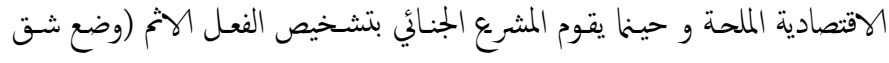

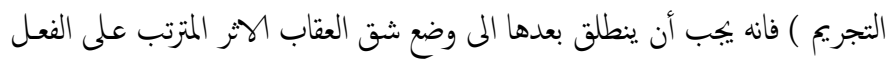

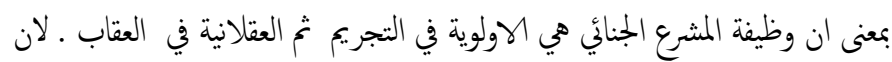

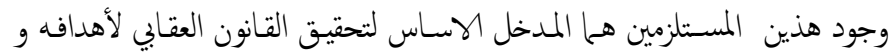

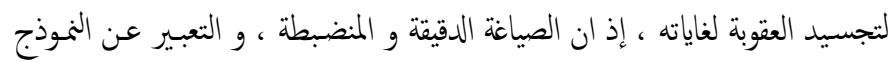

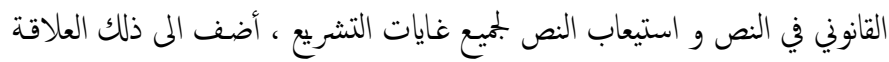

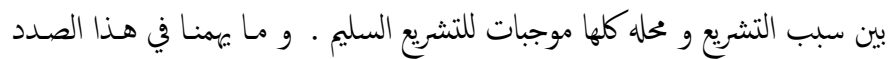

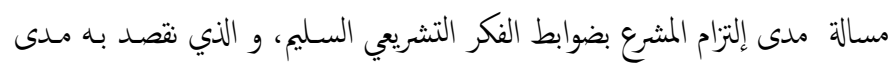

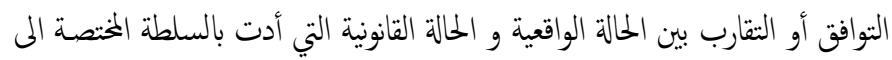

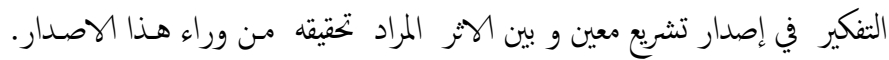

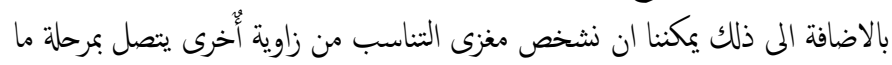

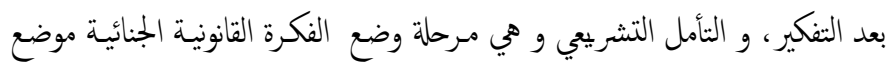
الصياغة التشريعية حيث نستقصي حينها عن مدى توافر العقلانية التشريعية و الموائمة

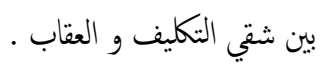

مشكلة البحث / ان مبنى البحث مرده الى موابهة مشكلة حقيقية متصلة بازمة

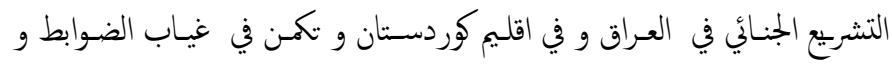

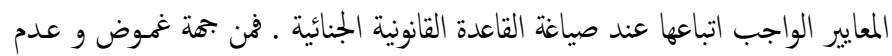

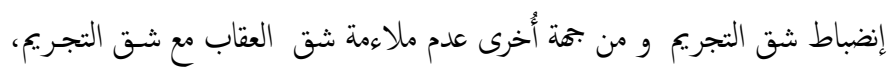

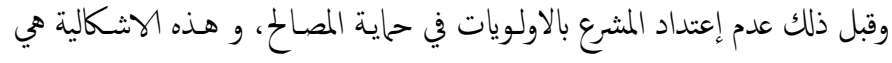
سمة من سمات العمل التشريعي الذي سنحاول إبرازه كونه مظهر من مظاهر الاخلال

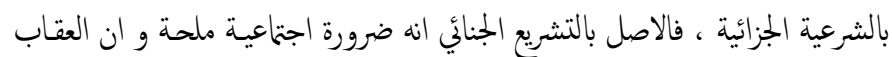

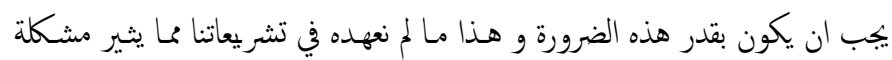
حقيقية في النعاطي مع الجريمة و الوصول الى الاحكام السليمة كون التشريع الجنائي السليم هو المدخل الصحيح في بناء الاحكام القضائية السليمة.
المستخلص - تسعى هذه الدراسة إلى تسليط الضوء على المعايير و القواعد

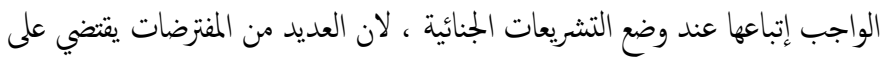
المشرع تبنهيا عند إنشاء القاعدة القانونية الجنائية و من بين هذه المعايير التشريع بناءً

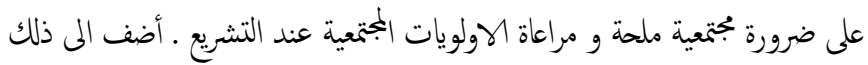

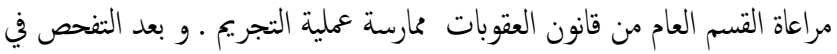

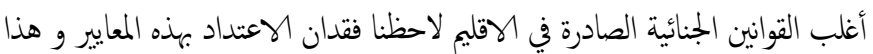

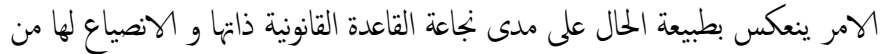

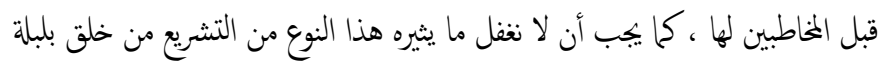

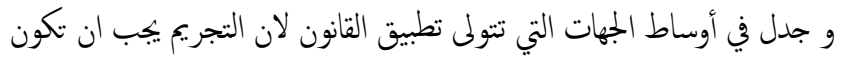

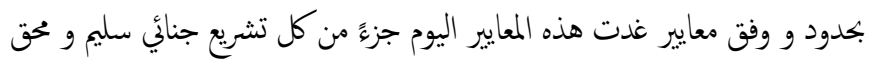

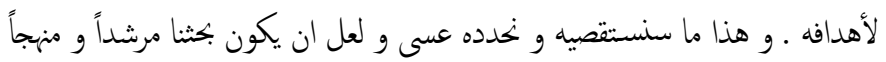
المشرع الجنائي عند سنه التشريعات الجنائية .

المقدمة

من المعلوم ان المفترض في التشريع الجنائي ان يكون تعبيراً و تجسيداً عن رد الفعل

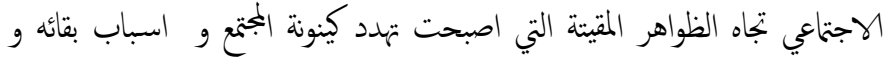

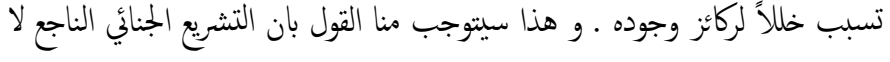

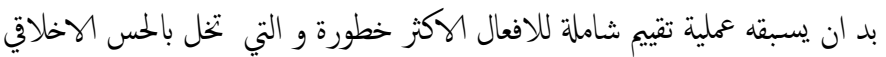

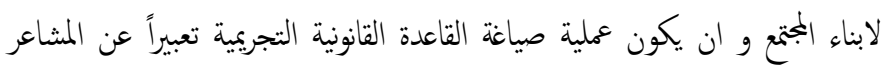

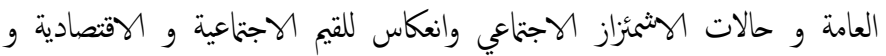

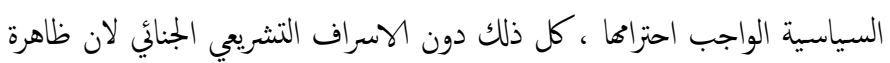

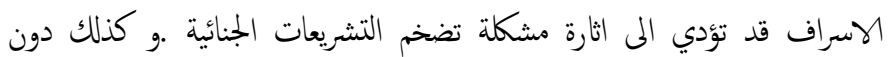

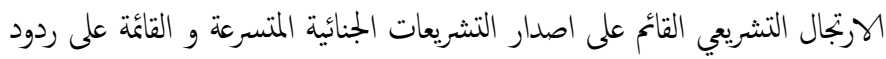

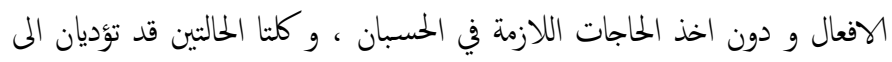

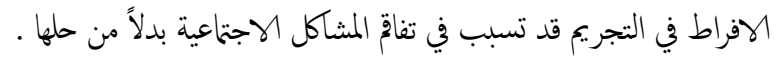

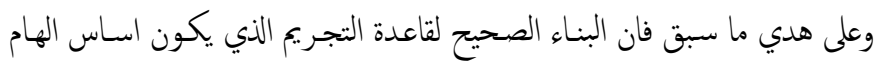

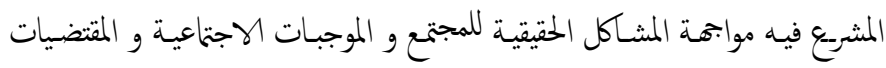


يقوموا به ومناط هذا الواجب المفروض عليهم هو حاية حقوق أخرى فالتجريم تقييد

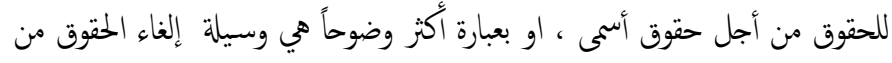

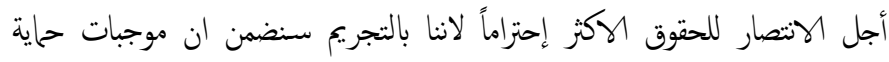

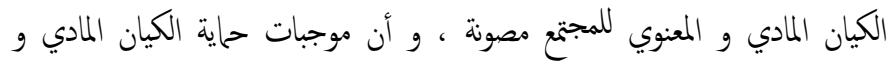

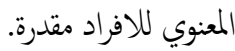
و يجب على المثرع عند سن أي تشريع ان يعلو و يسمو بالحقوق و التي هي مقررة

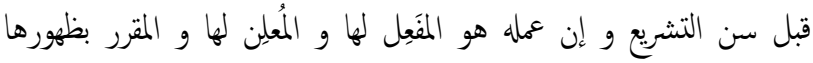

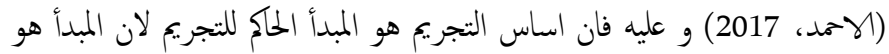

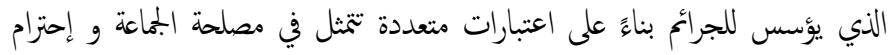

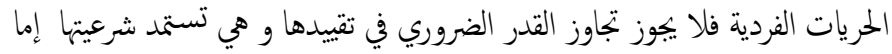

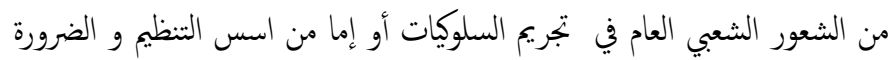

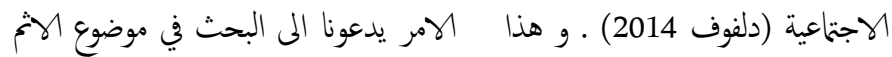
الجنائي و درجاته و صوره و ضوابط تحديده قبل الخوض في التناسب من عدمه في

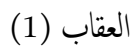
وطالما كان الانحراف متصلاً بموضوعي التجريم و العقاب فإن من اللازم ابتداءً أن

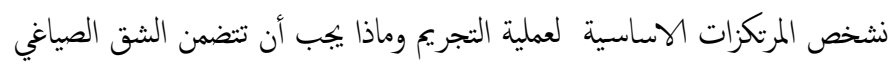

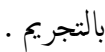
اولاً / الضرورة الاجتماعية كرتكز اساسي لعملية التجريم : قبل اللجوء الى سلى

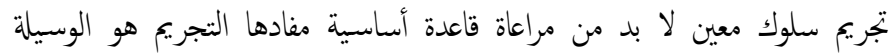

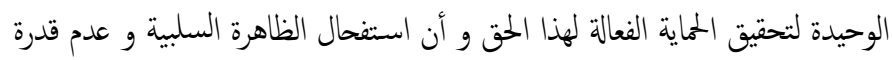

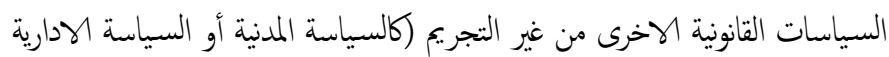

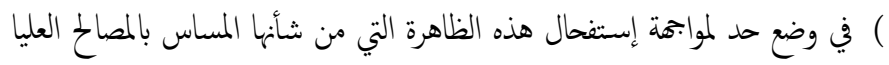

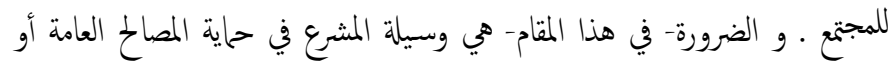
حاية الحقوق و الحريات التي تتعرض للضرر أو الخطر (الجادر و صالح ، 2013) .

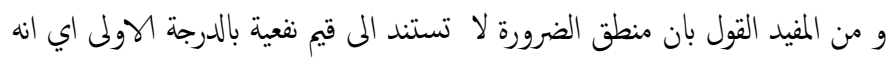

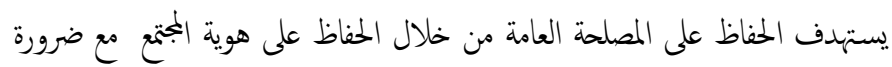

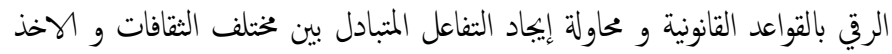

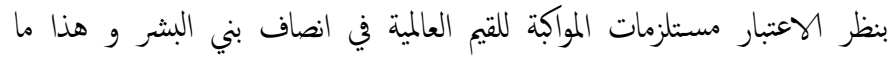

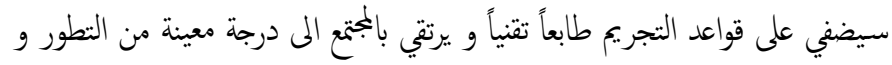

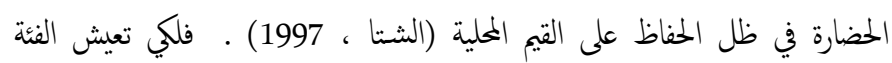

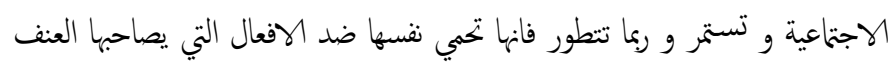

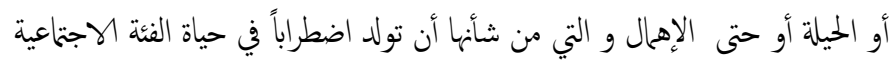

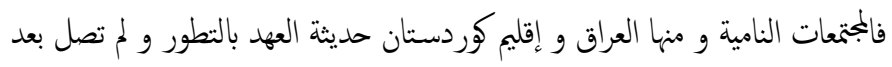

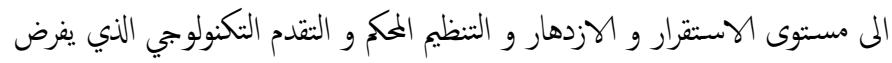

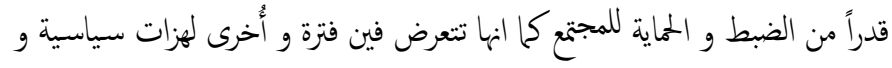

أهمية البحث/ إرتباطاً بما سبق فان اهمية البحث نكمن في بيـان صور الانحراف التشريعي التناسب و بيان المفاهيم المكونة لاطار البحث و المتمثلة باهم و أبرز

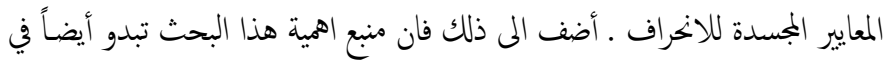

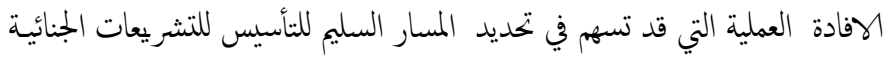

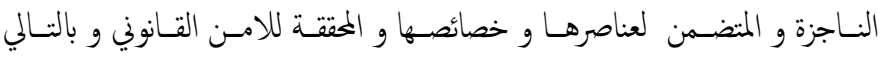

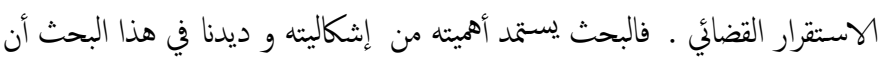

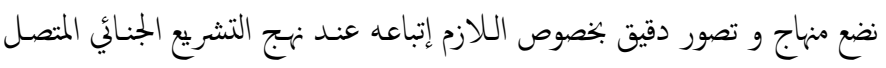
بوضع القاعدة القانونية الجنائية

منهجية البحث / إن الاسلوب المتبع في كتابة هذا البحث هو الاسلوب الوصفي

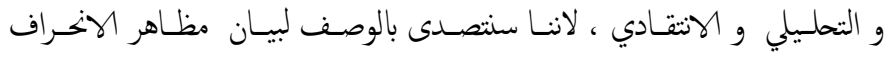

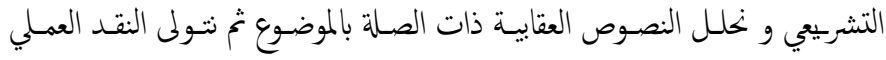

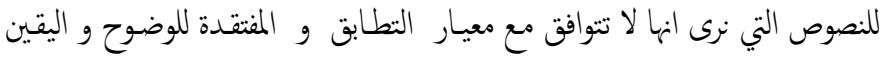

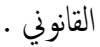

\section{هيكلية البحث / البحئ}

المقدمة المبحث الهول / الجوانب الموضوعية للانحراف في التشريع الجنائي

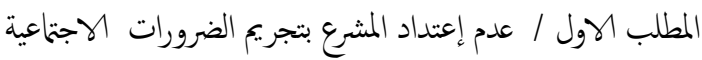

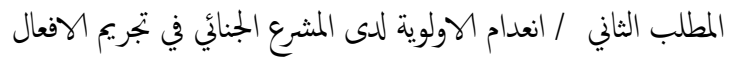
المبحث الثاني / الجوانب النظرية للانحراف التشريعي الجنائي

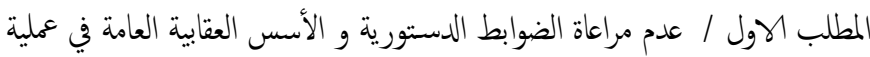
التجريم المطلب الثاني/ عدم الاعتداد بعماير الوضوح و اليقين في بناء النموذج القانوني للجريمة الخائة

\section{المبحث الاول \\ الجوانب الموضوعية للانحراف التشريعي الجنائي}

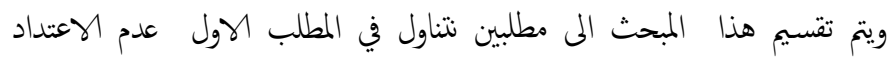
بمستلزمات الضرورة نخص المطلب الثاني للحديث عن الخصائص المميزة لانعدام التناسب في التشريعات الجنائية .

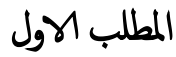 \\ عدم الاعتداد بمستلزمات الضرورة في التشريع الجنائي

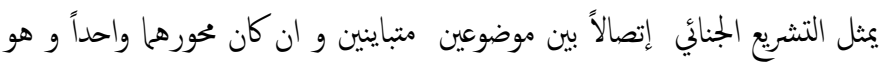

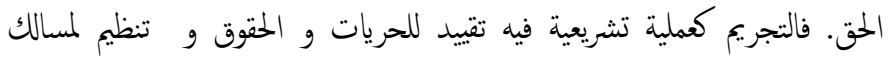

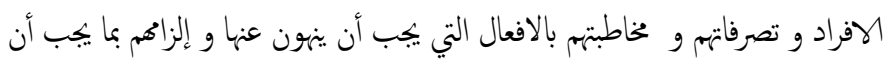


• ويرى البعض (الهيتي ، 2013)ان الاستقراء البسيط لتطور التأريخي للمصاح المحمية ضمن نطاق قانون العقوبات تعكس التحولات التي تلحق بالهيكل العام اللقيم

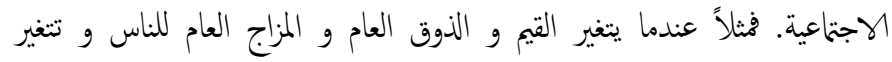

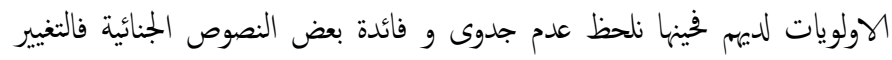

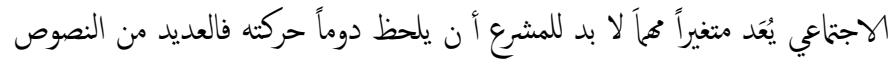

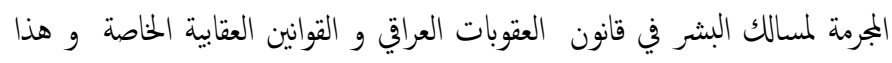

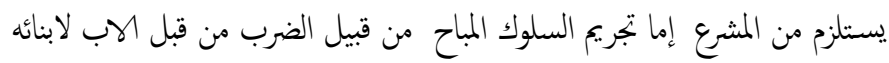

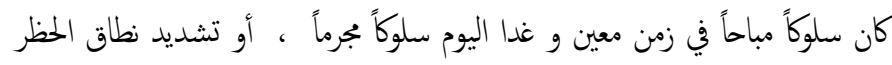

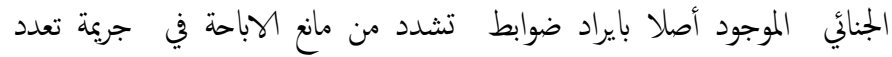

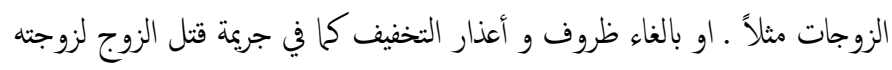
أو أحد محارمه مثلاً.

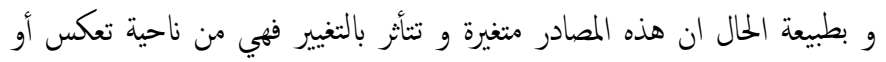

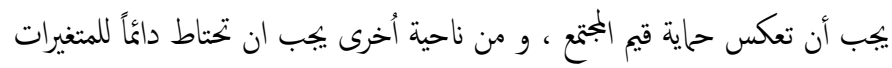

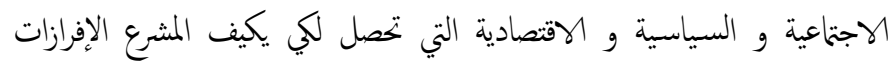

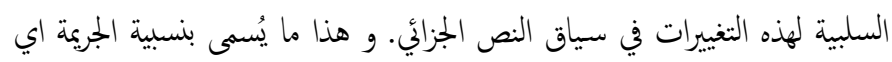

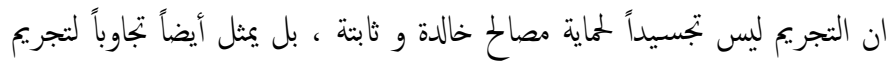

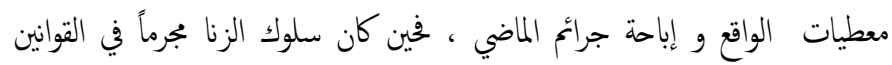

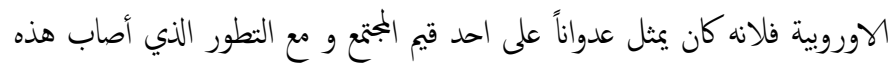

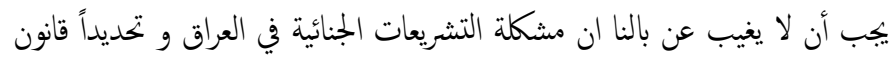

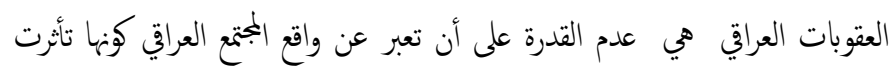

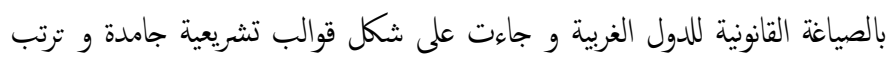

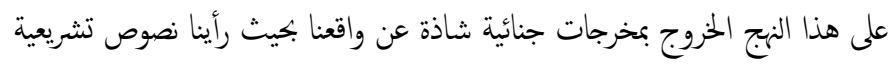

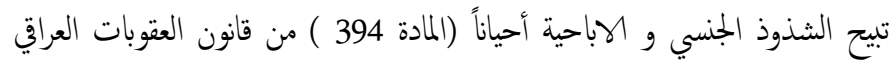

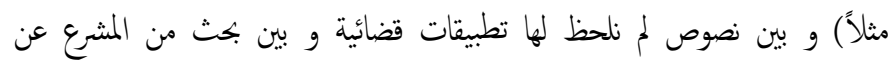

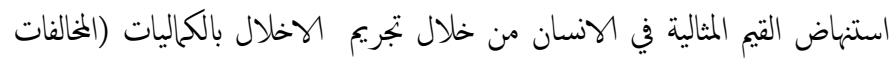

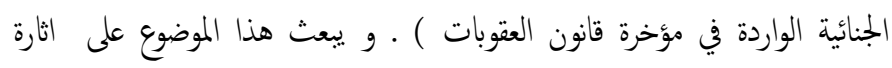

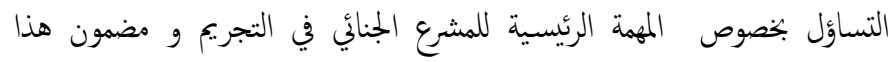

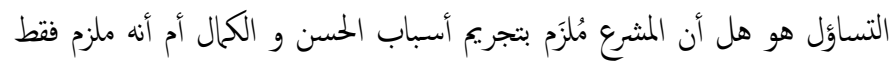

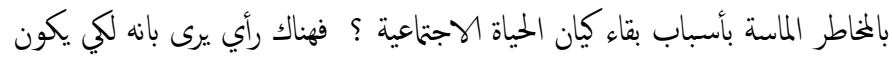

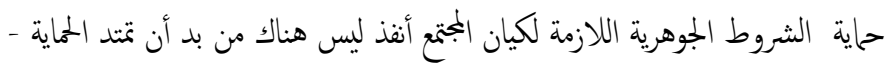

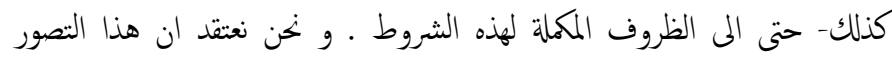

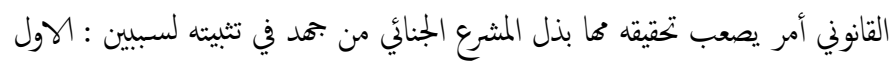

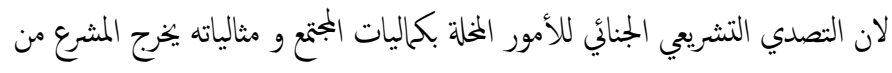

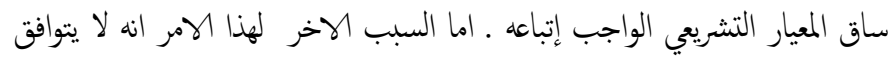

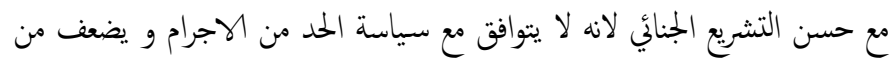

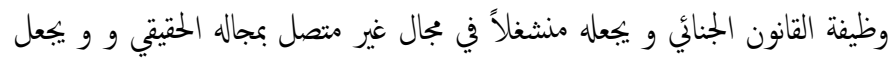

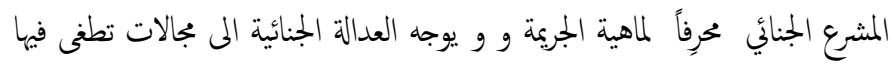

إقتصادية و إجتاعية تفقد معها الطابع المستقر للنفوس و هذا بدوره يفرز الحاجة المتجددة للتشريع الجنائي ، لان الامن و السلم ركيزتان أساسيتان لبقاء و إستمرار

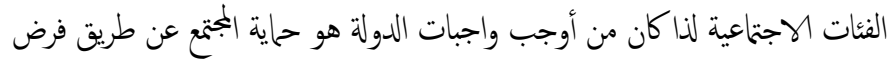

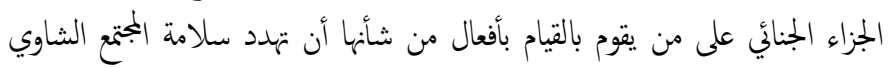

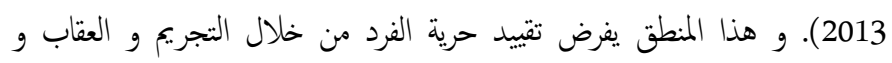

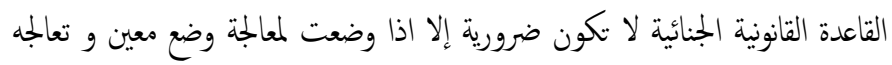
على نخو كافٍ بغير مبالغة (سرور ، 2000)

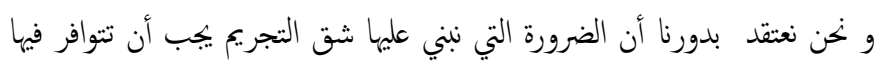

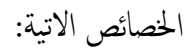
1- أن يكون النص الجزائي هو الملجأ التشريعي الاخير في حاية الحق المعرض الضضرر

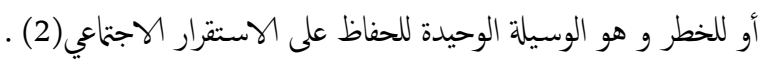

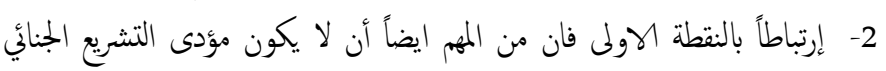

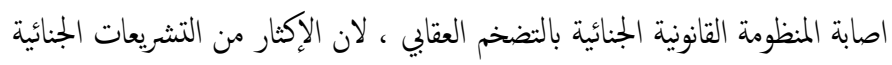

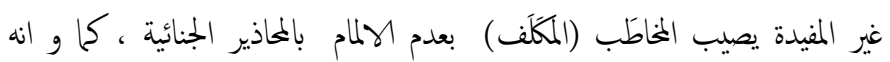

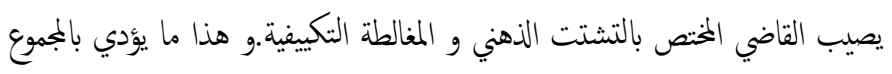
المى إصدار الهحمام الجنائية الخاطئة.

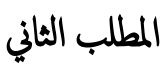 الانحراف في تحديد مصادر الالهام التشريعي}

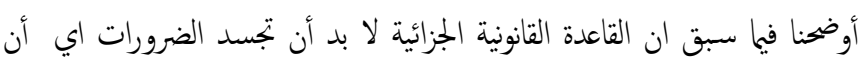

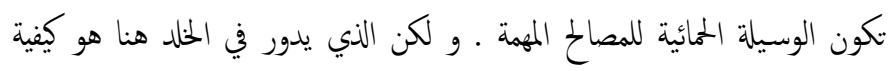

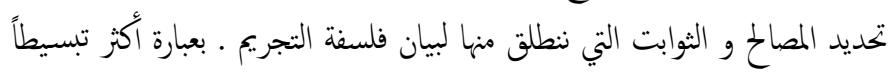

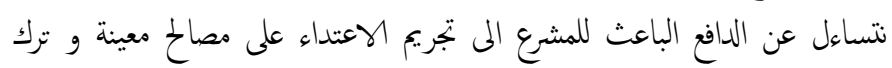

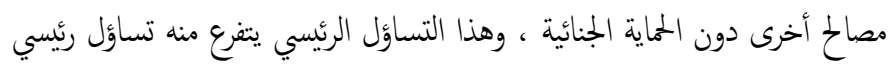

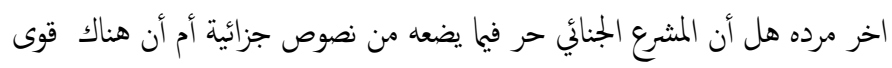

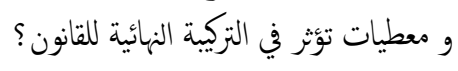

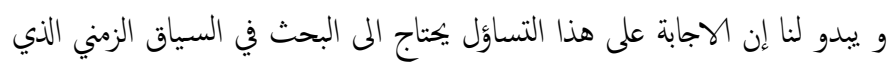

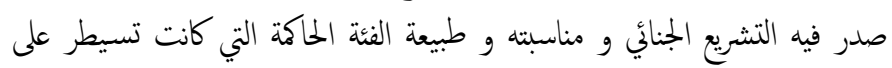
السلطة وقت إصداره ، و فلسفة الحكى ، و التصور الاقتصادي لمواجهة المشاكل

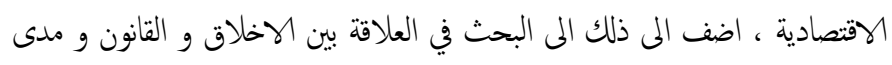

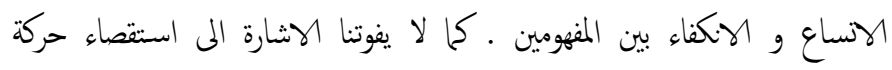

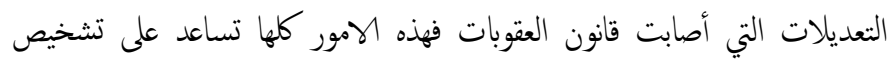

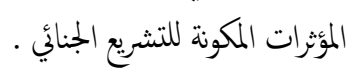

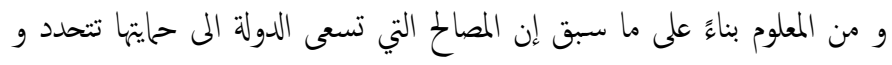

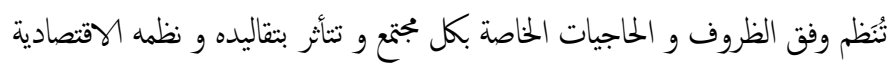


لعب الاخلاق دوراً ملهاً للمشرع الجنائي في صياغة القواعد الجنائي بشكل نسبي

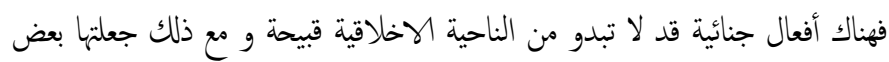

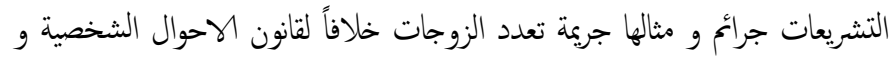

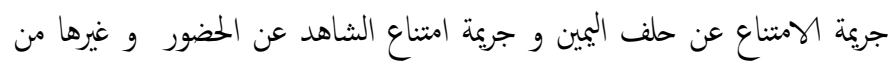

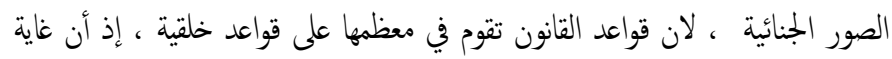

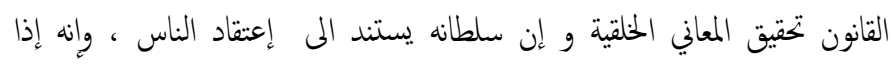

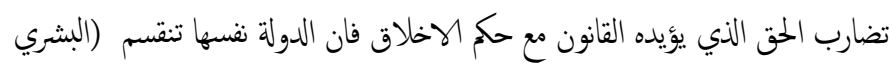
، 1996) . و إرتباطاً بذلك فان العديد من نصوص القانون العقابي العراقي متأثرة

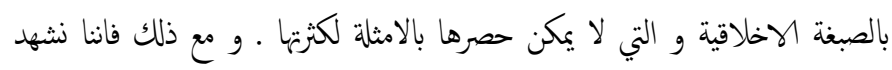

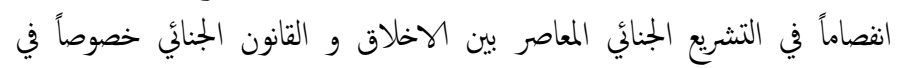

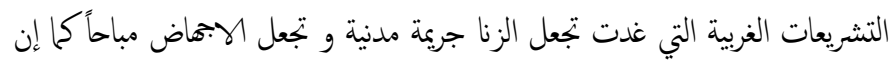

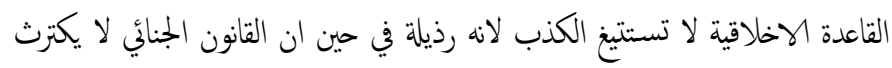

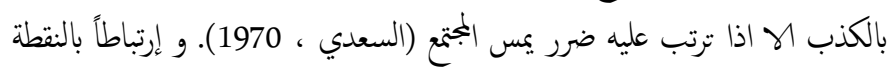

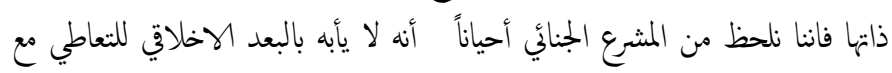

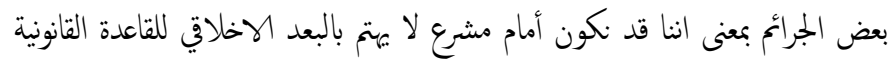

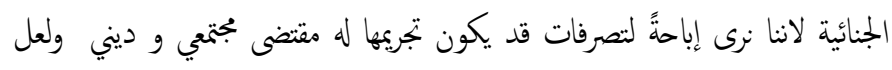

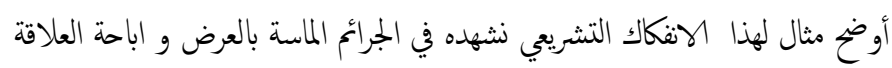

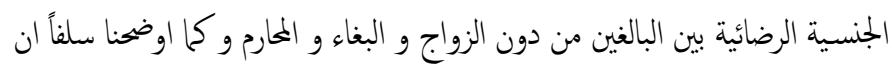

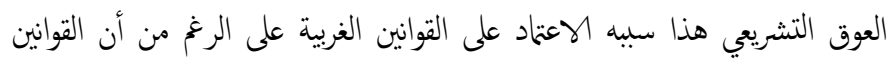

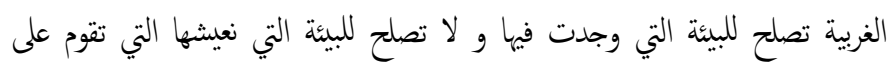

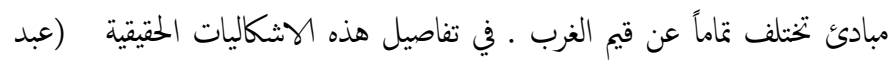

الشافي ، 2009).

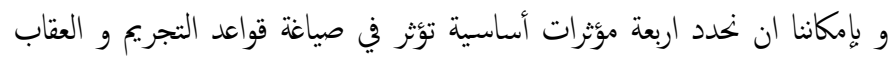

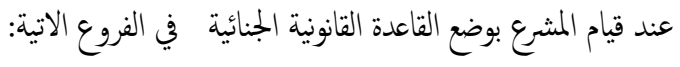

\section{الفزع الهول \\ أثر العامل السياسي كصدر من مصادر الالهام التشريعي}

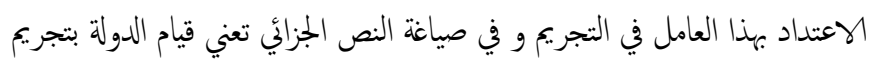

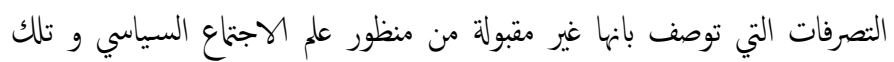

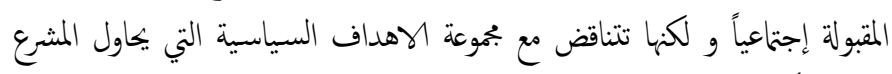

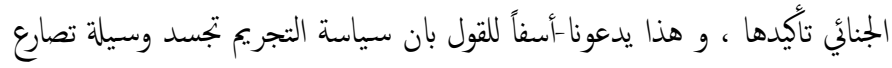

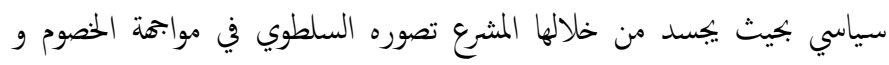

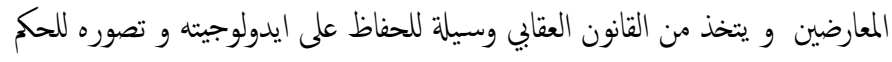

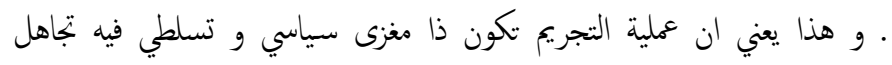

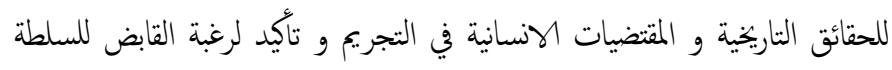

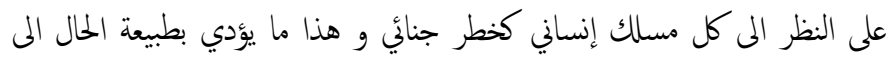
توسع واضح في سياسة التجريم ـ فالدول التي شهدت ثورات أو إنقلابات تلاهيا
الطابع الاداري مما يضلل الرأي العام و من المستحسن ان لا يستهدف المثرع الجنائي

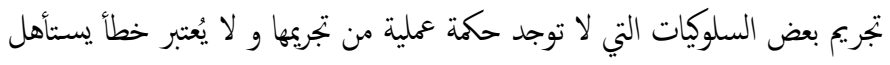

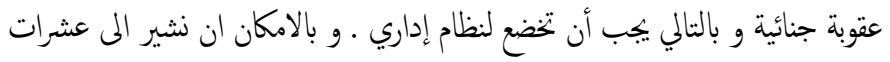

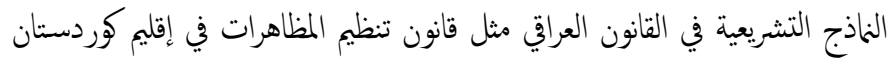

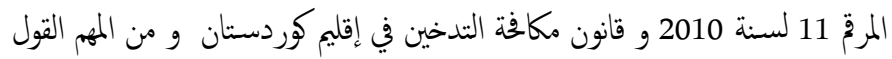

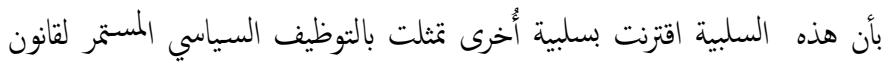

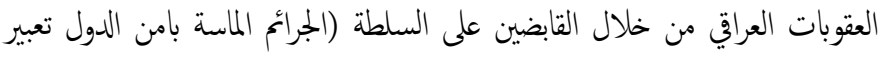

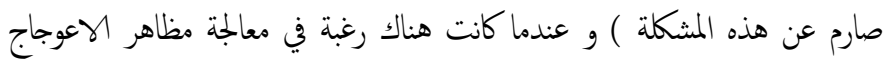

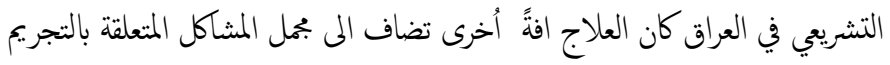

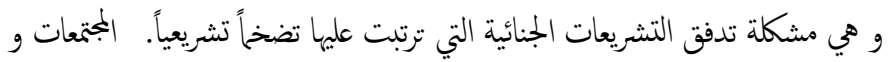

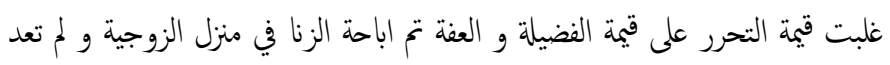

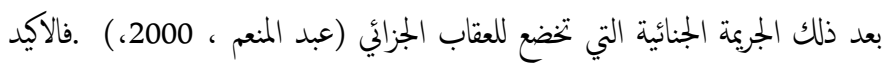

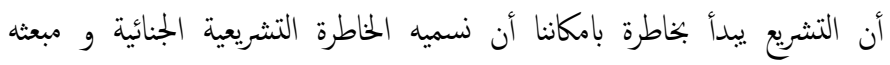

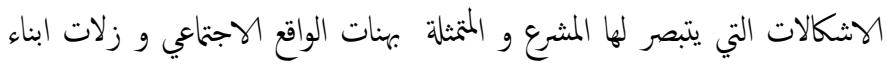

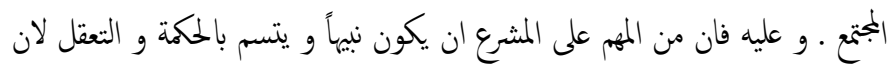

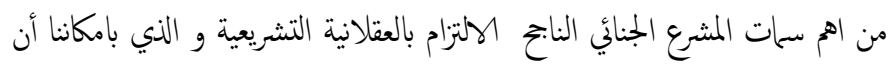

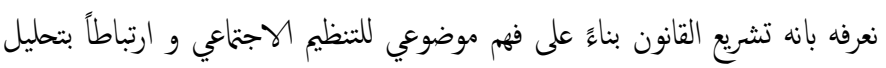

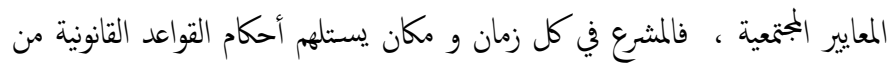

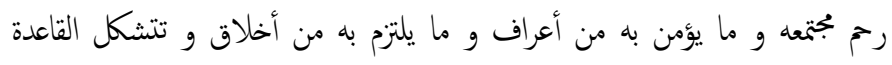

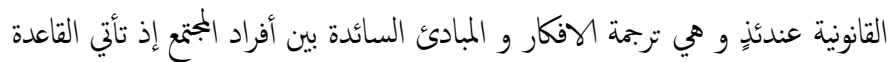

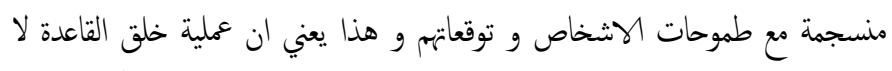

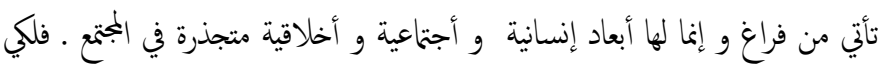

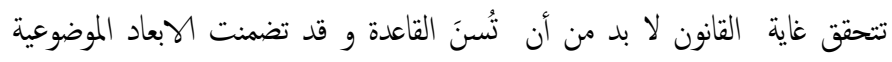

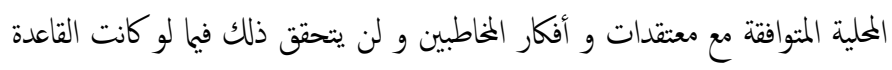

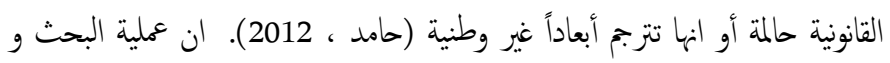

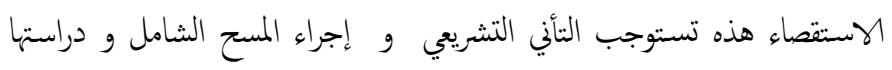

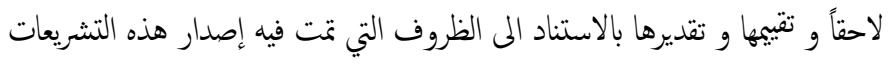

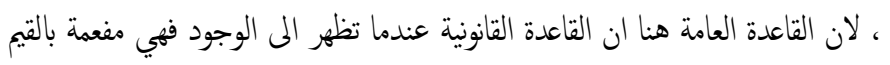

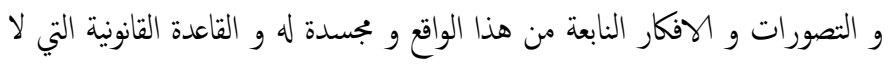

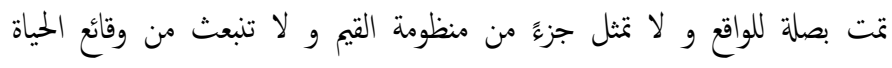

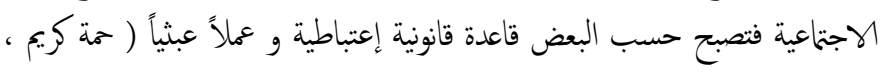

.(2012

و إبتناءً على هذا التصور السابق فان المشرع الجنائي يجب أن يأخذ في الحسبان

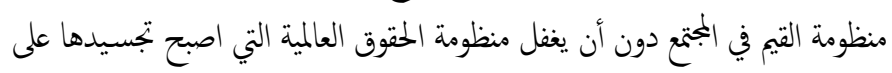

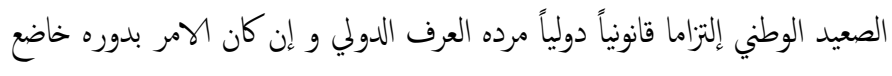

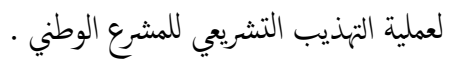




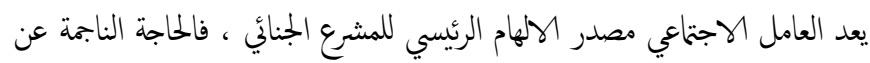

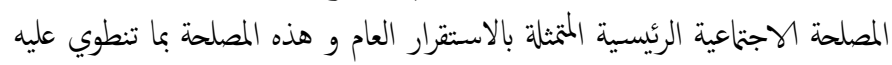

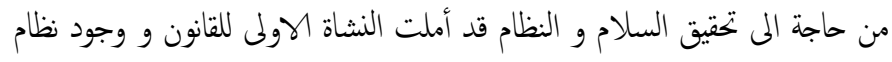

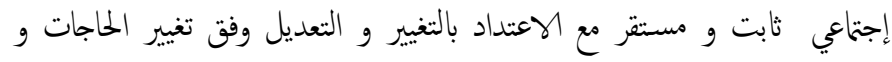

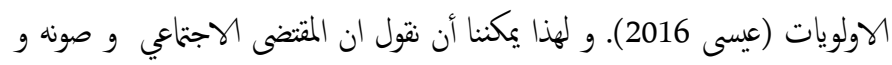

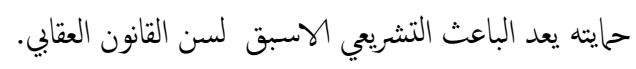

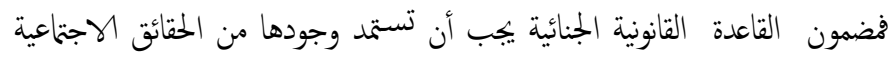
المحلية و التي تتجسد فيها طبيعة الانسان ، وهذا يعني أن القاعدة القانونية الجنائية

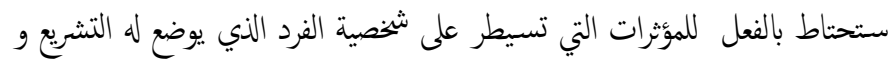

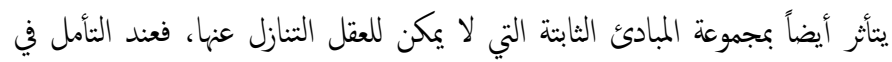

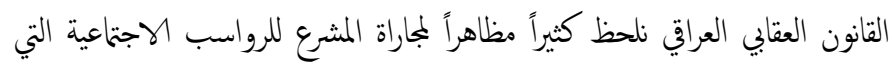

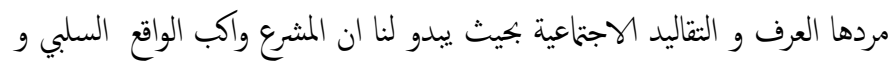

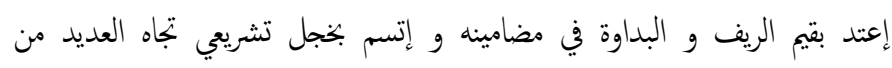

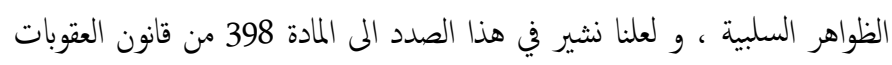

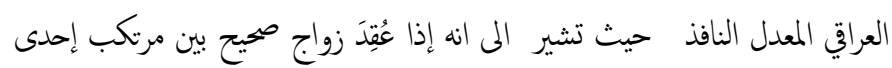

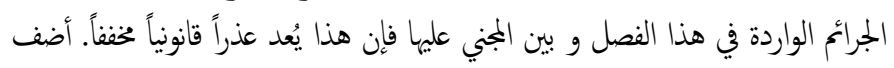

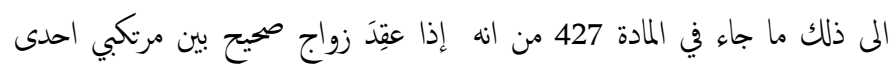

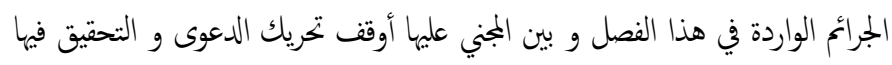

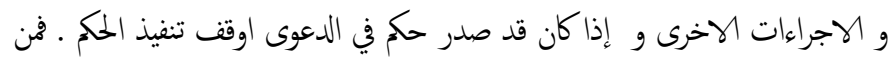

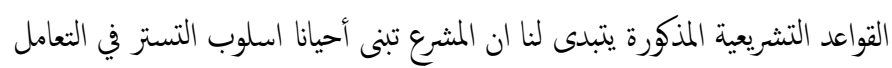

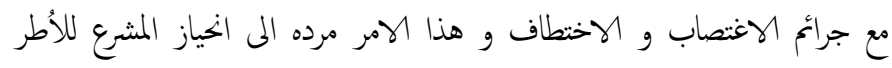

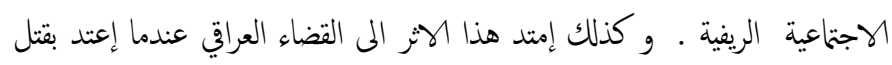

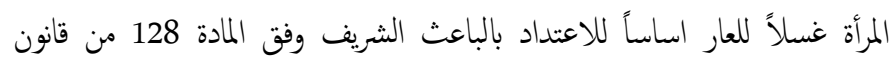
العقوبات العراقي و عد الامر عذراً مخفقا للجاني.

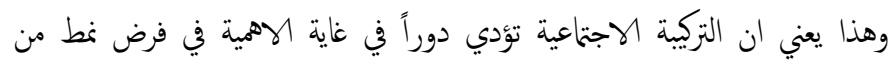

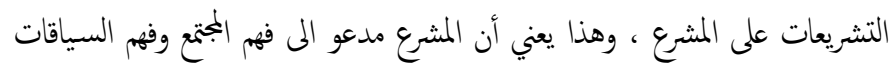

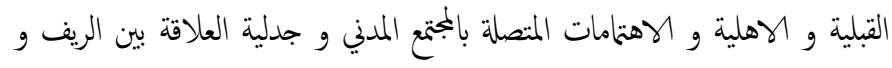

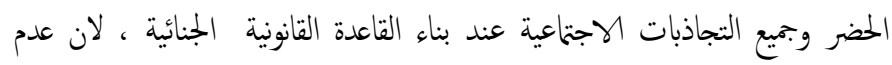

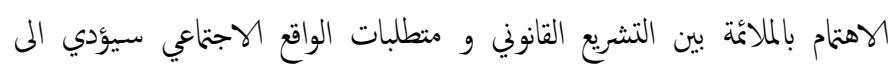
ظهورمشكة عدم الاستقرار القانوني(سعيد 2013) .

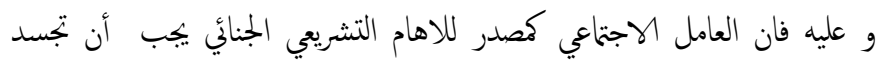

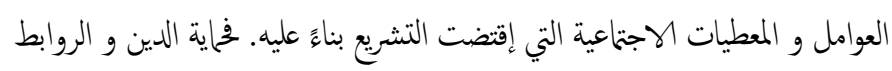

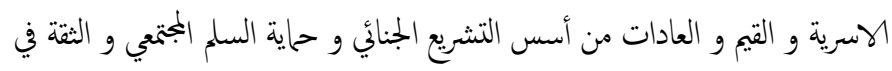

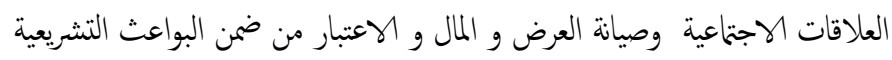

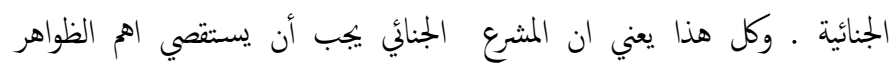

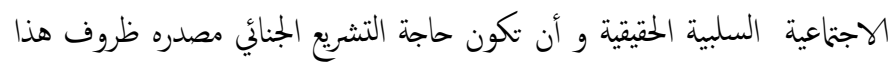

مراحل إنتقالية سعى فيها صانعو القانون الى تبني تشريعات ذات طابع سياسي التي

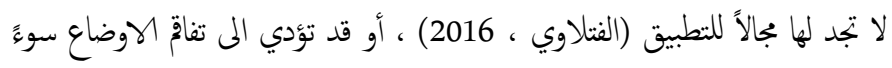

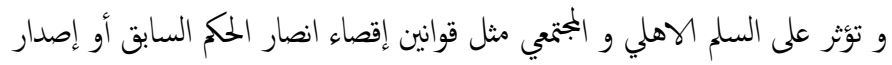

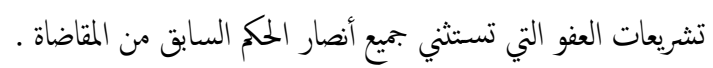

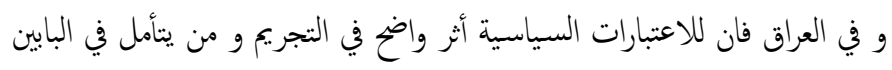

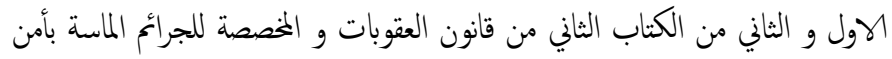

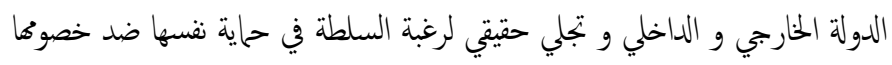

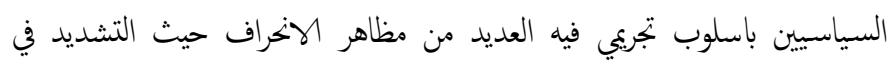

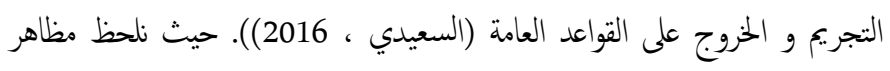

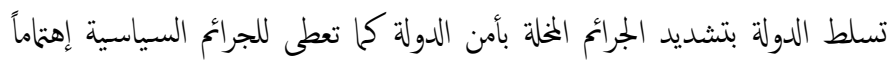

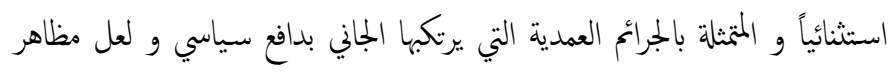

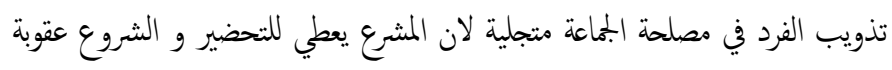

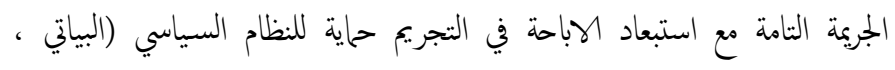
. $(2002$ وقد حاول المشرع الكوردستاني أيضا تبني تشريعات جنائية تجسد إنغكس

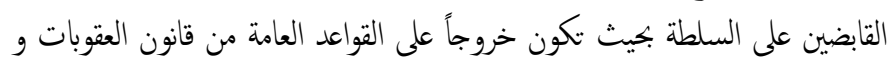

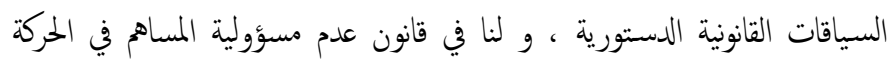
التحررية الكوردية لشعب كوردستان جزائياً و مدنيا رث 13 لسنة 2012 مثلالاً بارزاً

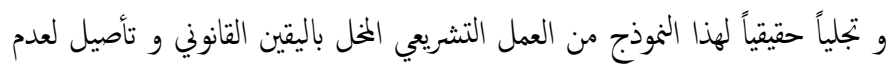

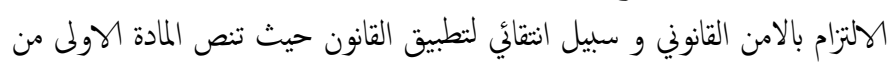

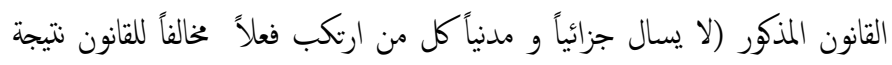

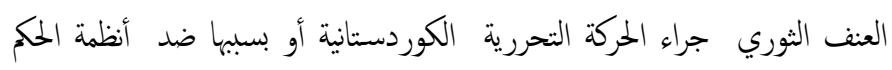

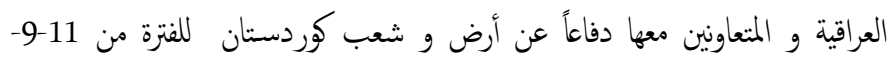

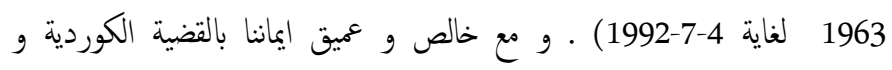

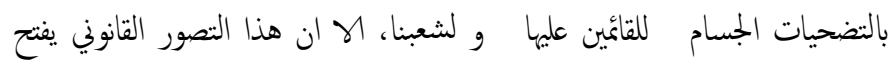

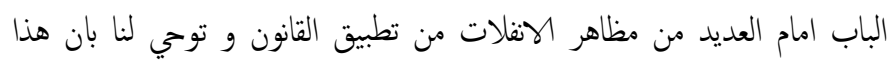

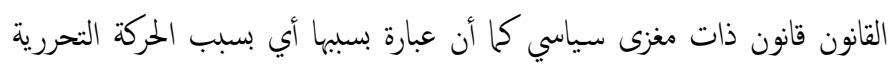

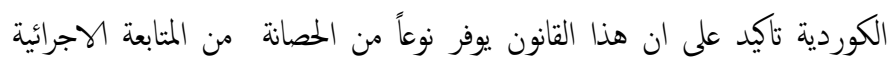

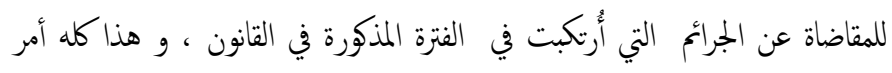

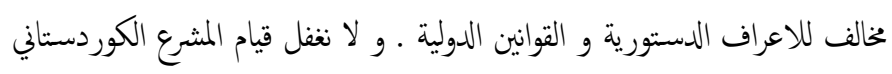

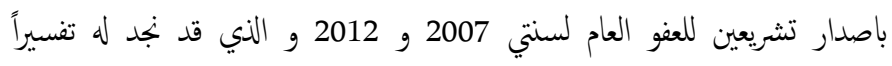

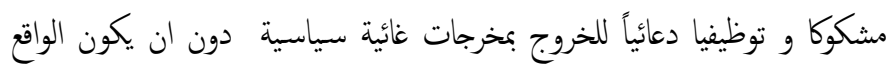
الاجتاعي يتطلبه و دون ان تكون جزءً من منظومة الحل الاجتاعي .

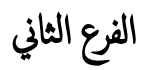

أثر العامل الاجتمي كصدر من مصادر الالهام التشرييي 
إلحاق العار به ـ و مع إعتقادنا الراسخ بان المادة 409 من قانون العقوبات العراقي يمثل

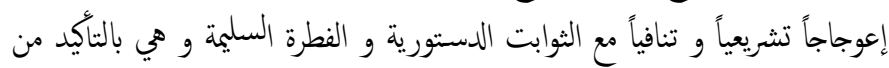

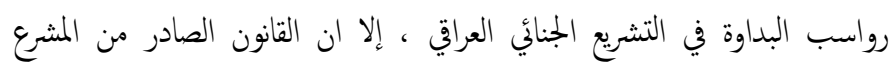

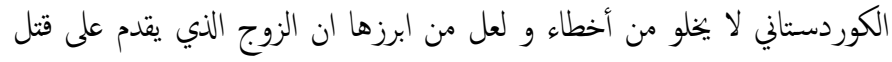

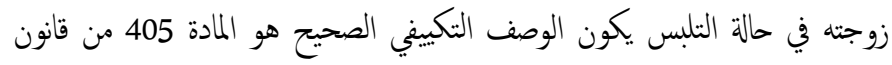

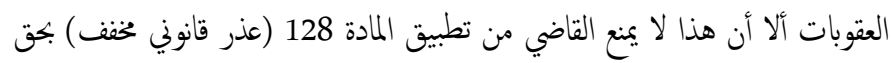

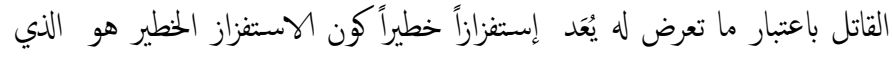

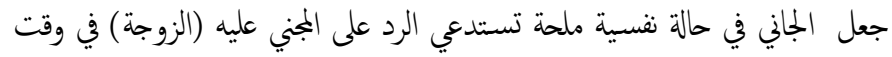

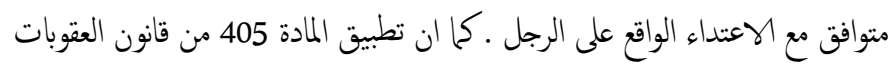

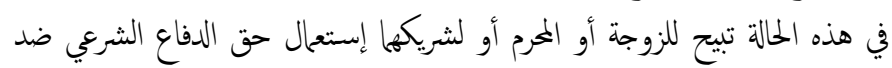

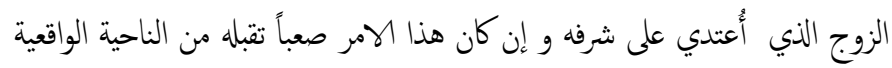
و المنطقية. و نحن نتتقد ان التعاطي مع الموضوين السابقين يجب أن لا يفسر على انه تضاد أو

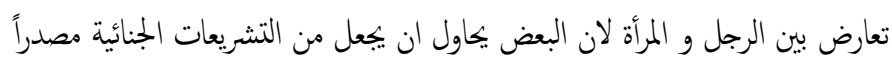

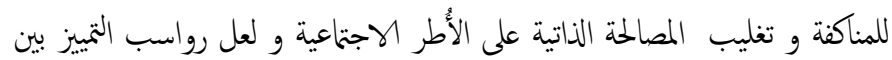

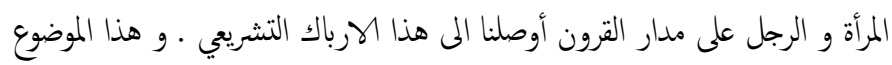

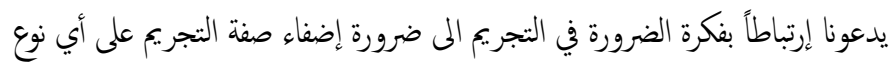

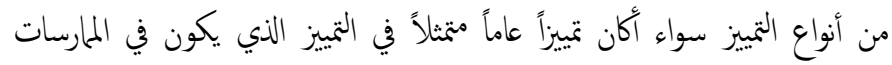

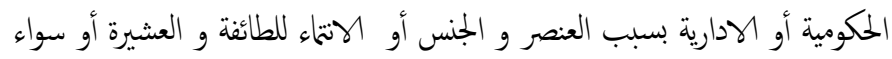

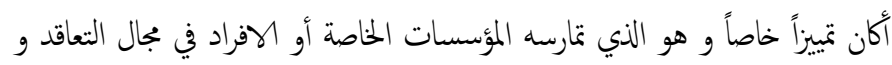

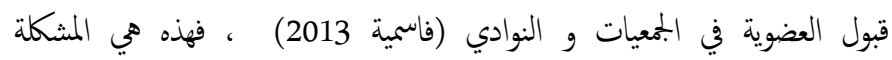

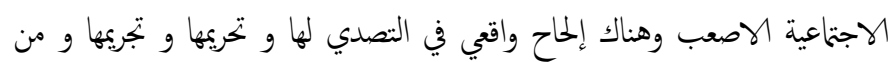
خلال ذلك بالامكان تبني التشريعات السلمة التي تنتصر للانسان قبل التاني التفكير بالرجولة و الانوثة.

\section{الفرع الثالث}

\section{العامل الاقتصادي كصدر من مصادر الالهام التشريعي}

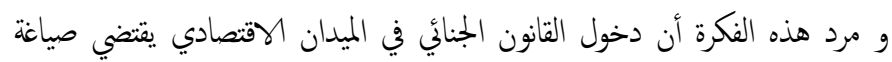

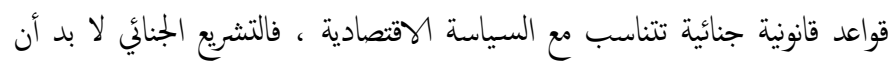

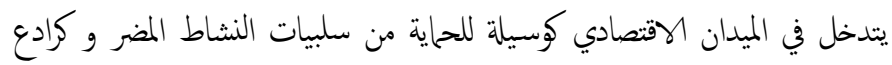

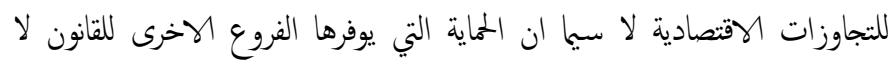
تتناسب مع خطورة الجرم الاقتصادي (عمر 2017).

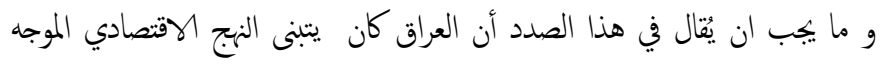

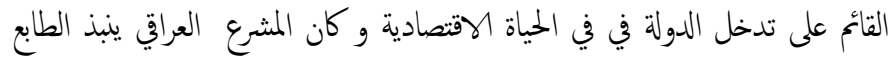

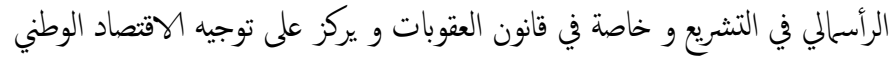

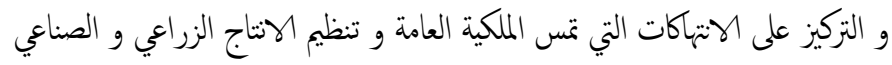

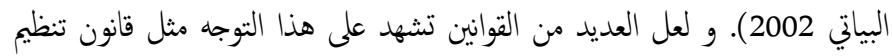

اليجتع دون أن تكون للمؤثرات الخارجية أي أثر مباشر على التقنين، إلا إذا كانت عالمية. و هذه الفكرة المذكورة سلفاً يدعونا الى استقصاء التشريعات الجنائية التي لها بعد

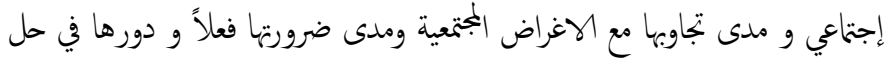

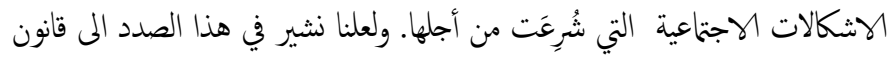

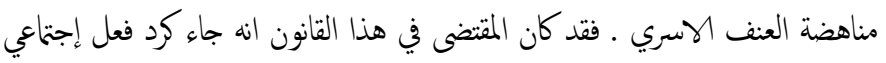

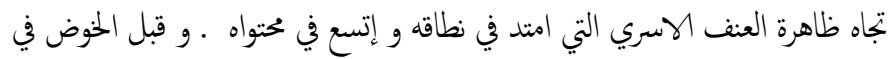

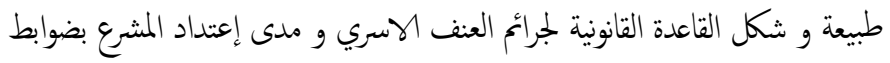

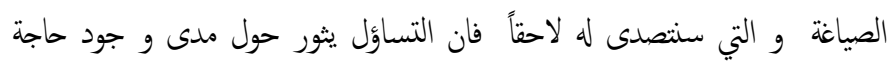

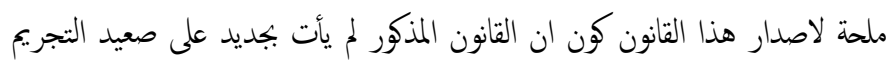

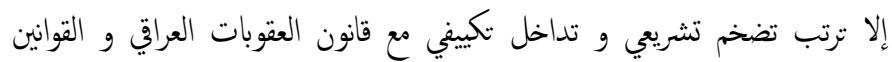

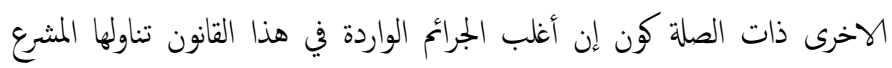

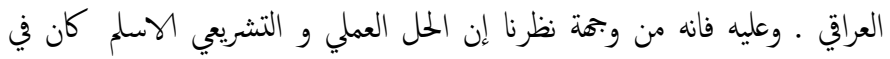

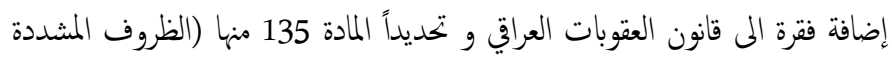

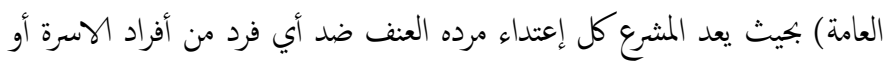

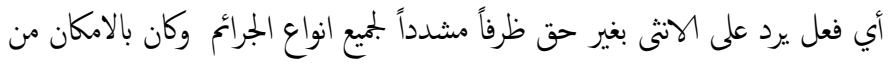

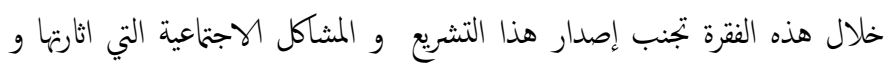

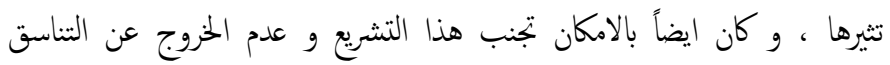

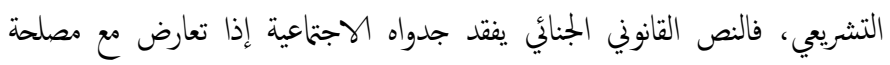

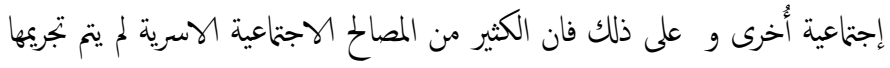

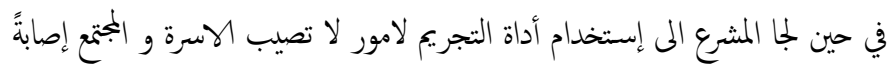

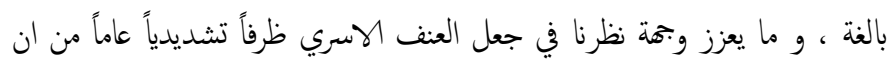

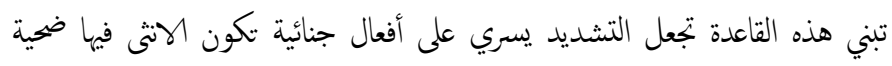

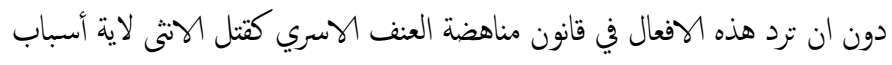

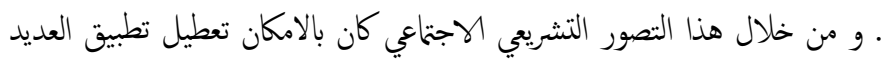

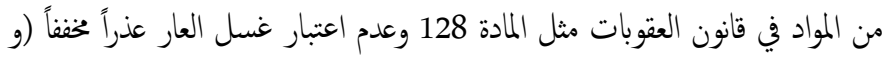

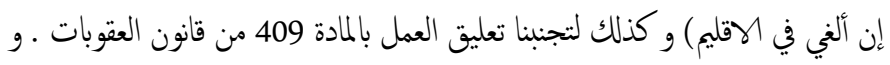

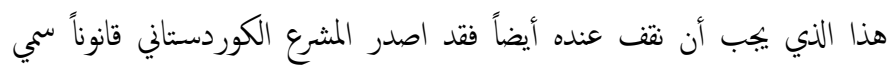

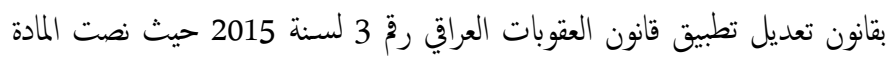

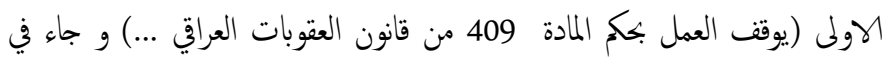

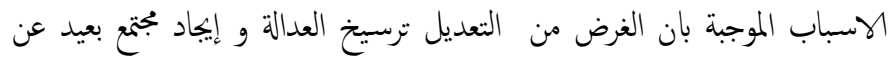

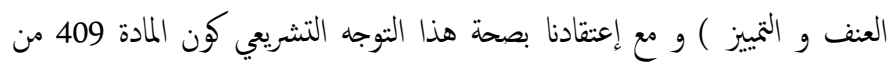

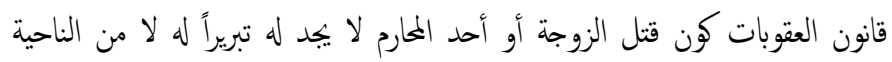

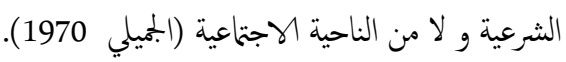

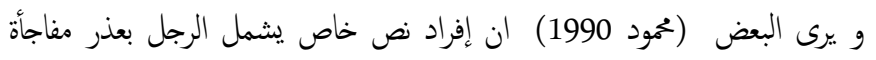

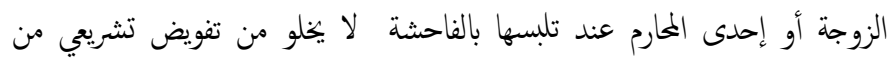

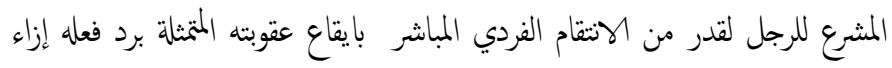


لتسخير إمكانيات العالم لصالخ الانسانية جمعاء ، فهي دعوة أخلاقية تسعى لجلب

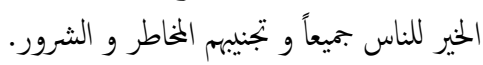

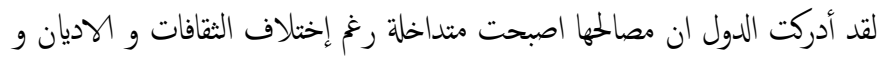

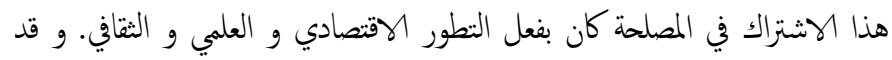

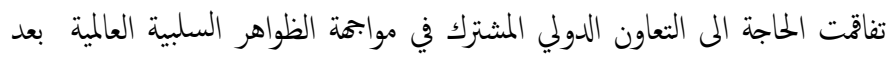

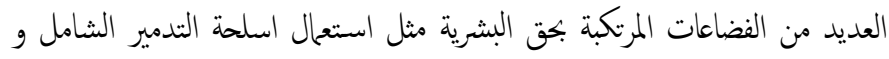

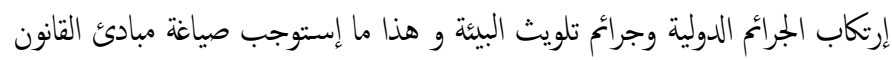

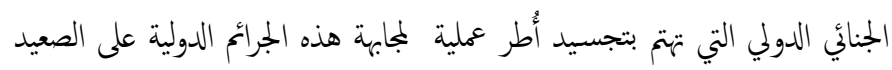

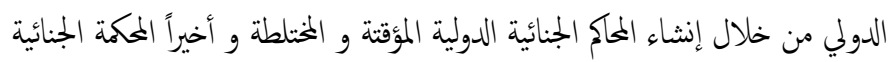

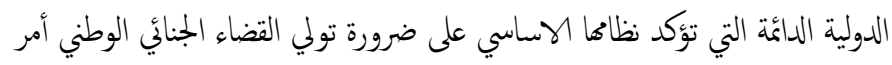
المقاضاة عن الجرائم الدولية حسب قواعد الاختصاص النكاملي و هذا يعني ضمناً ضرورة تقنين الجرائم الدولية على صعيد التشريع الجنائي الوطني لكي تتولى الدئي الدول أصلاً

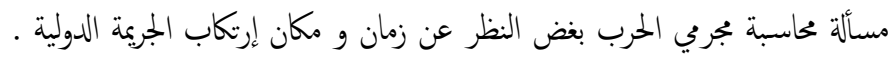

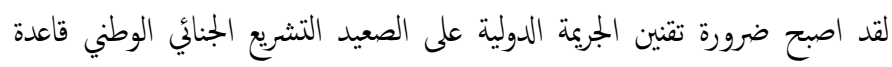

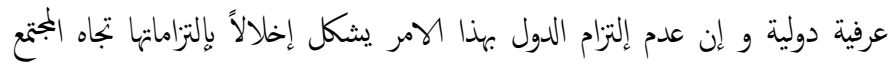

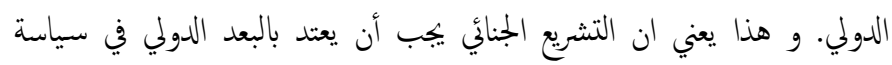

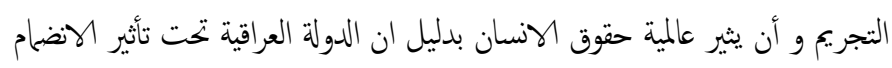

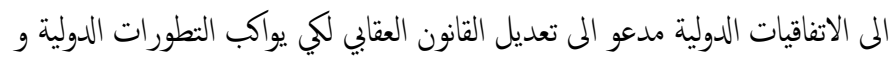

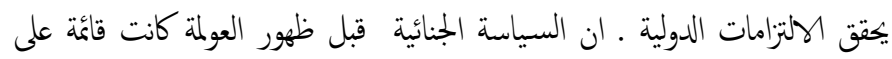

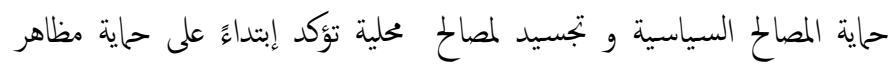
التسلط ، إلا ان حالة العولمة فتحت الافاق أمام العالم لكي تتابع الحركة التشريعية

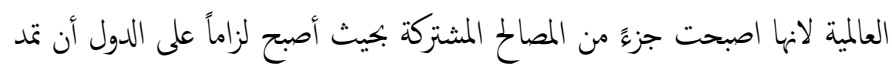

المعاهدات الدولة الى تشريعاتها الوطنية.

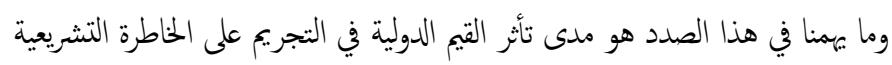
لدى المشرع الجنائي في إقليم كودستان و هذا ما سنجمله في الملاحظات التالية:

الملاحظة الاولى / إن المشرع الجنائي في إقليم كوردستان العراق لم يدور في تئل

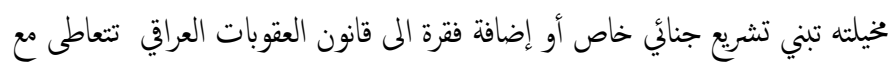

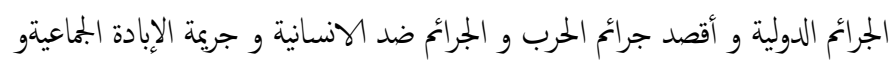

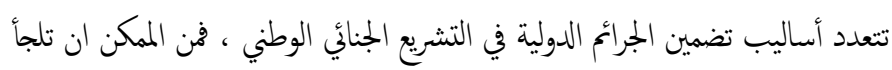

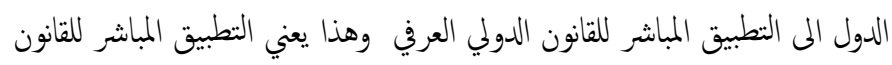

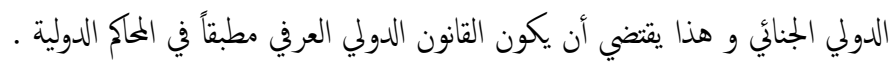

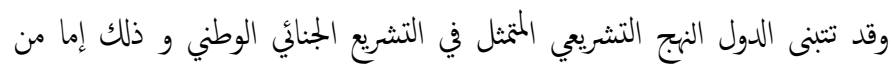

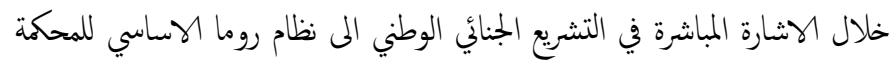
الجنائية الدولية وذلك باصدار تشريعات تعترف بالنظام الاساسي للمحكمة الجنائية

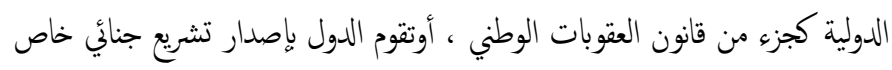

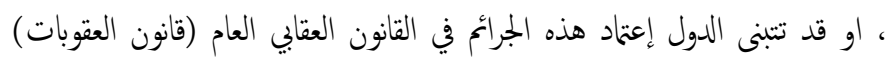

التجارة لعام 1970 و قانون حاية و تنمية الانتاج الزراعي لعام 1978 ـ و أرتباطاً

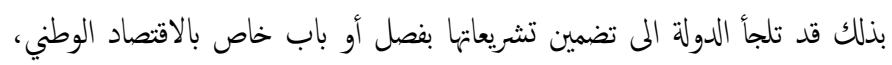

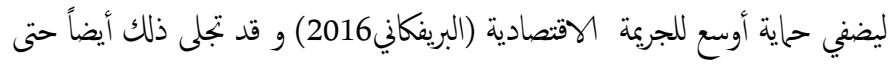

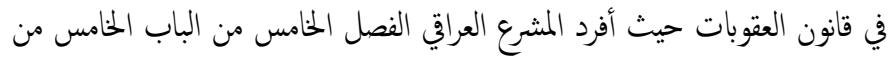

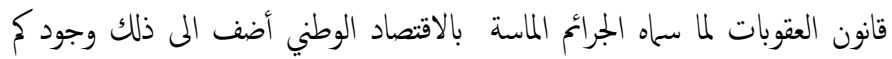

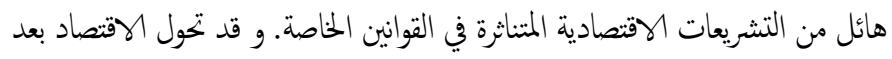

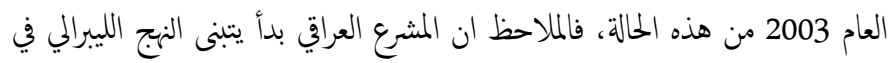

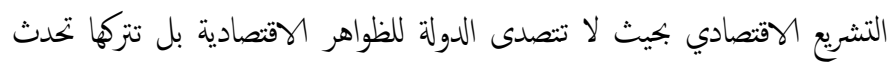

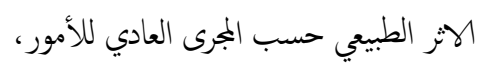

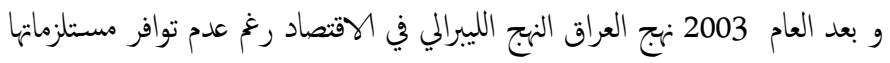

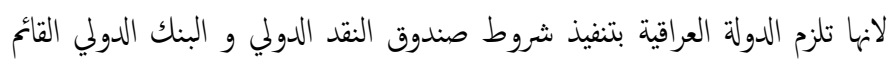

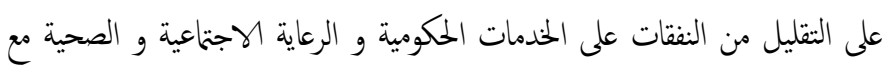

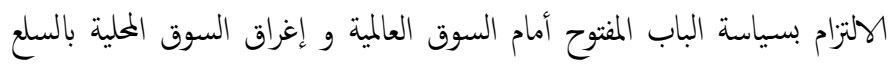

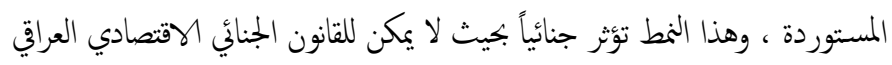

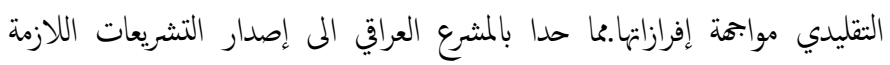

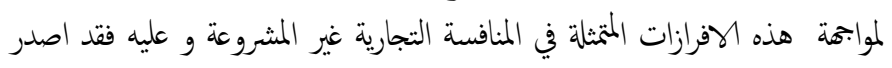

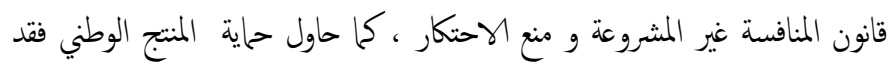

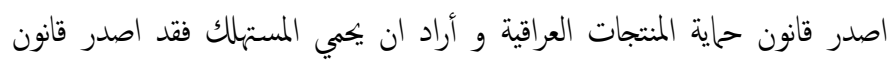

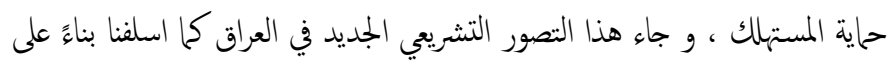

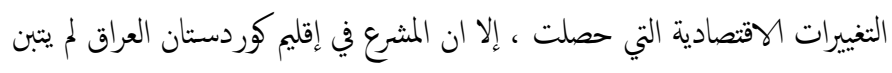

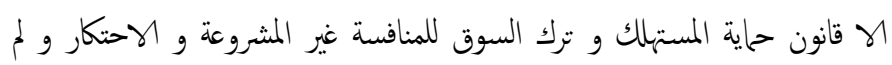

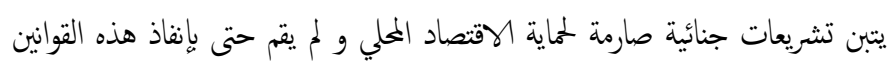

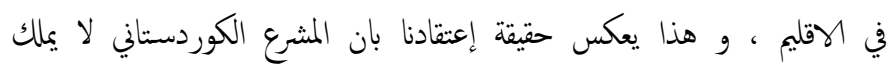

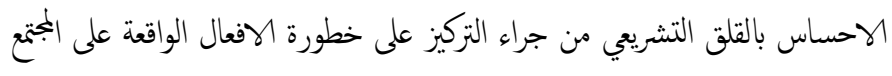

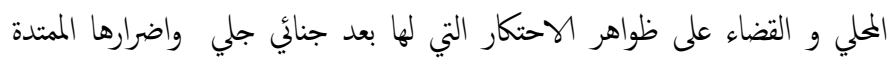
لازمان مختلفة . و عليه فان مظهراً من مظاهر الانحراف في التشريع الجنائي في الاقليم

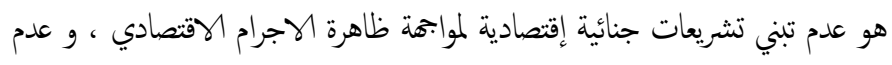

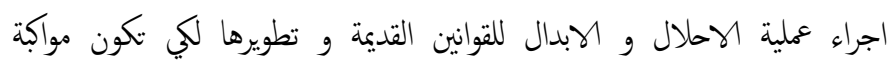
للتطورات الاقتصادية الناجمة عن ظاهرة العولمة .

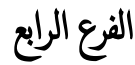 أثر القيم العالمية في التجريم على عملية التجريم المللي}

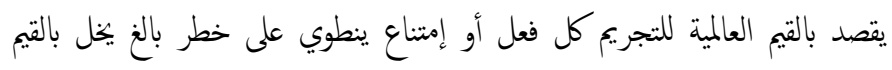

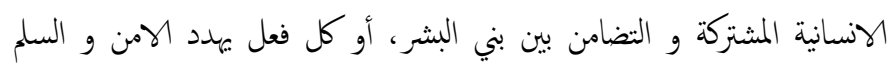

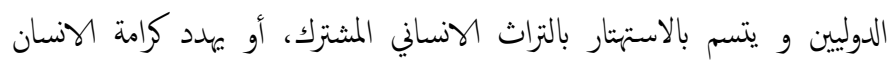

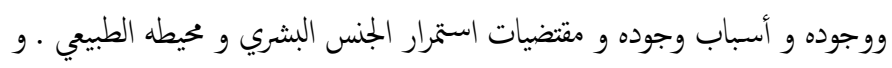

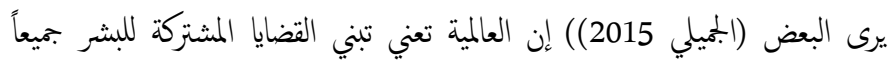


أوسع مما ورد في المادة 333 من قانون العقوبات العراقي ـ لان المادة الثانية من الثفاقية

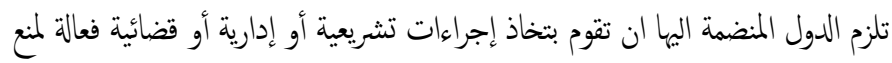

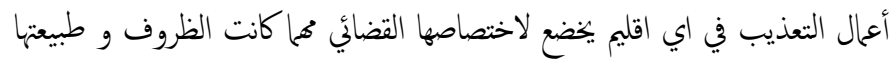

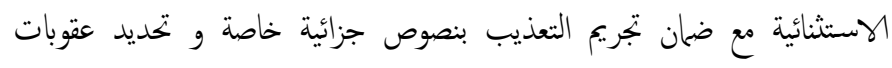
مناسبة تزاعي درجة الجسامة المادية للجريمة .

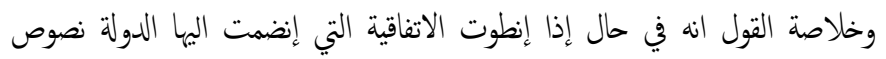

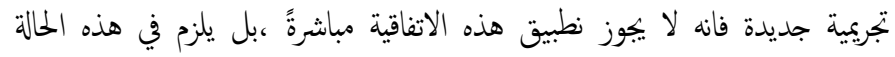

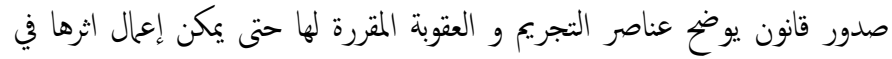
تعديل التشريعات السارية في الدولة و لا يملك القاضي في هذه الحالة تطبيقها مباثرةً (شمس الدين 2014) و هذا ما لم نشهده في اي تشريع جنائي في العراق أو في اقليم

$$
\text { كوردستان. }
$$

\section{المبحث الثاني \\ الجوانب النظرية للانحراف التشريعي الجنائي}

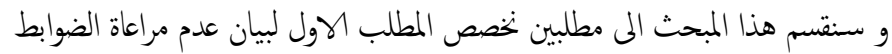

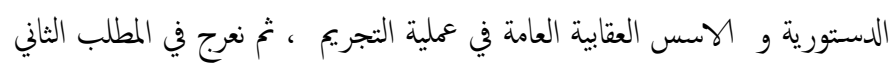

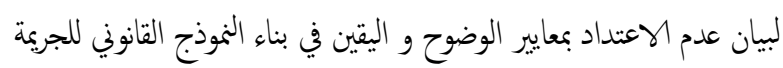

\section{المطلب الاول}

\section{عدم مراعاة الضوابط الدستورية و الاسس العقابية العامة في عملية التجريم}

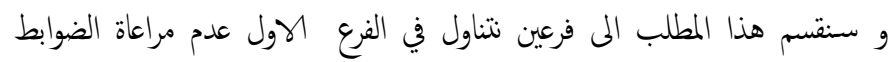

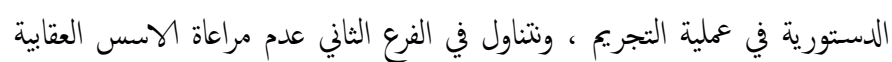

\section{الفرع الاول}

\section{عدم مراعاة الضوابط الدستورية في عملية التجريم}

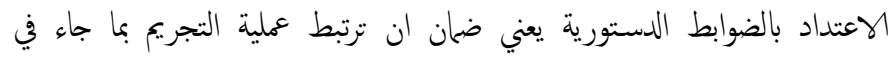

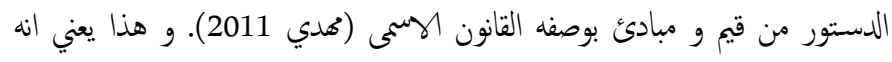

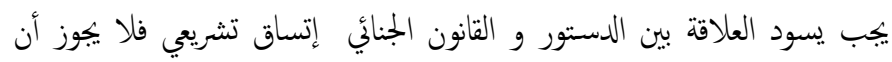

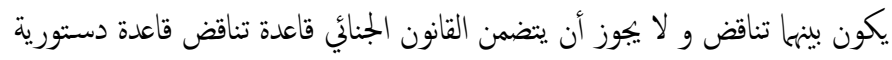

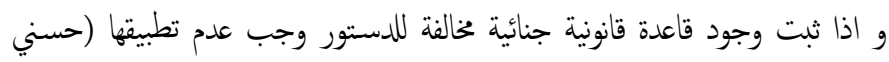

. (1992

لقد أوضحنا سلفاً ان التجريم يجب أن يتم اللجوء اليه وفق الاعتبارات السياسية

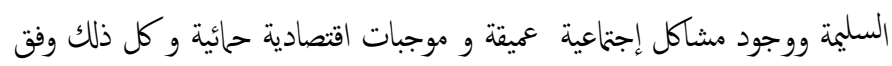

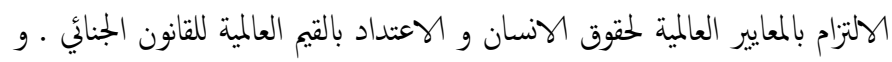

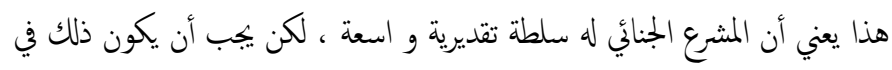

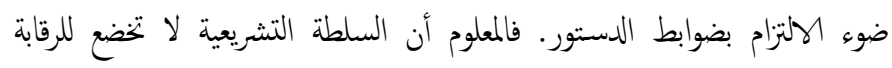

وذلك بإستحداث نص أو مادة قانونية تتضمن هذه الجرائم و إن كل طريقة من هذه الطرائق لها فوائدها و عيوبها (Kricker 2015)

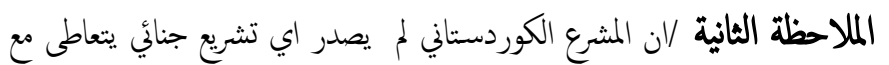

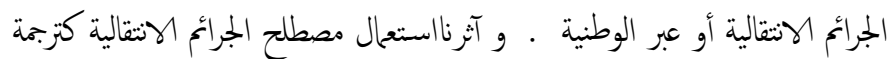

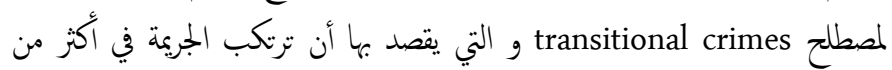

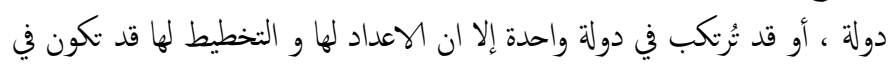

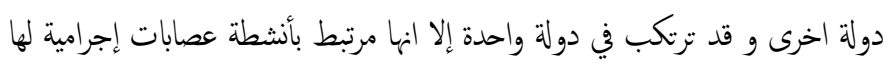

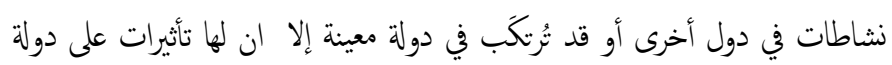
أخرى. للنفاصيل في تحديد ماهية الجرائم الانتقالي > (Boisterm 2012)

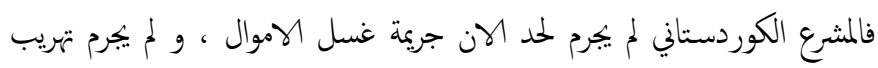

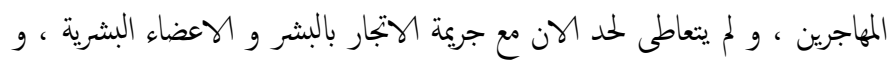

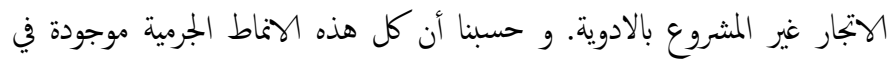

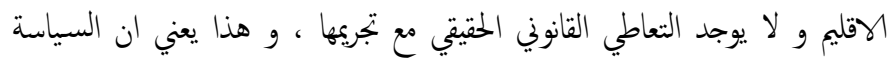

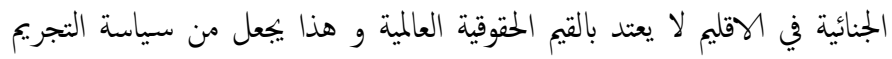

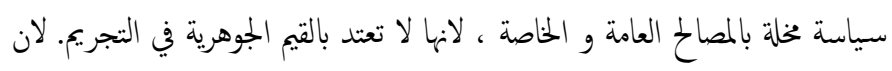

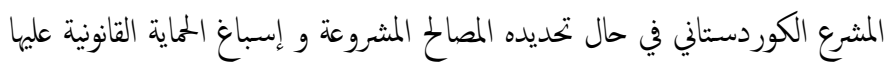

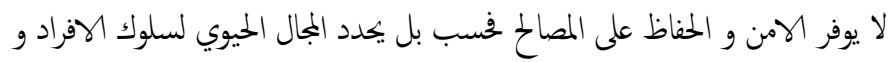

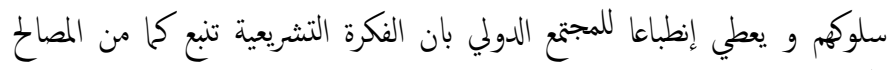

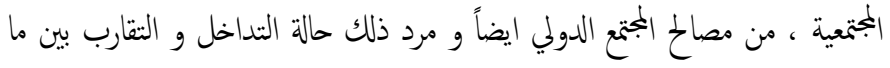
يعد مصلحة وطنية في و مصلحة عالمية في التجريم بمعنى أن المشرع الكوردستاني مدعو الى تبني العالمية في سياسته التشريعية الجنائية. الملاحظة الثالثة/ إرتباطاً بانضام العراق الى العديد من الاتفاقيات الدولية و إلتزاماتها

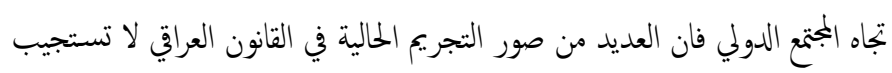

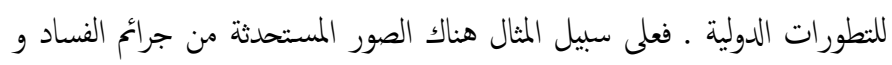

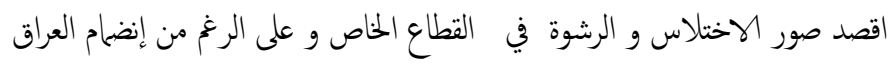

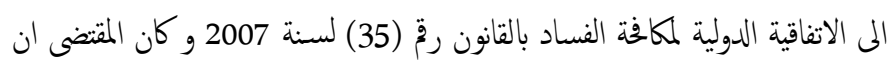

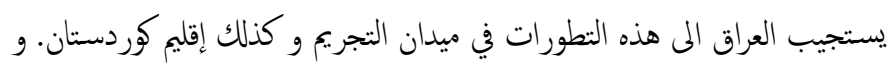

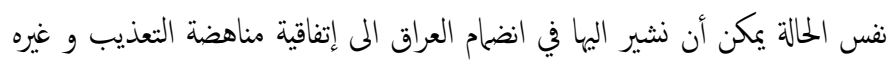

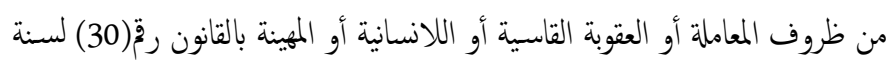

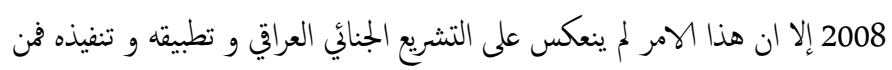

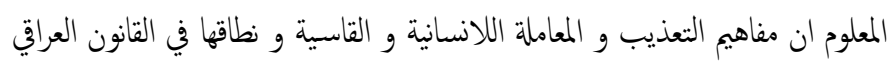

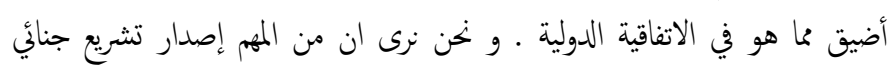

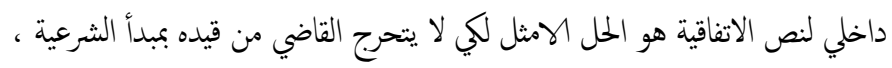

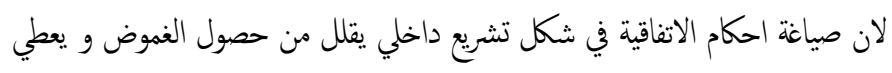

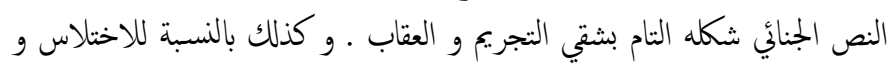

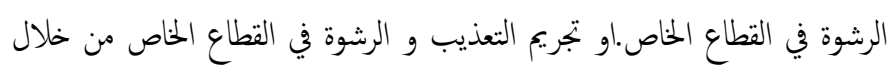
اضافة فقرة أو مادة الى قانون العقوبات لان لان غاية التعذيب حسب الاتفاقية الدولية 
دينار كل من خالف أحكام هذا القانون و الانظمة و التعليمات الصادرة بموجبه) و في

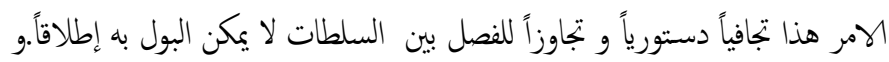

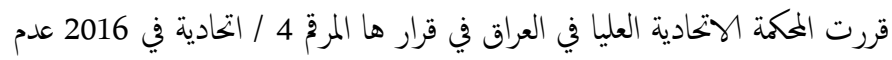

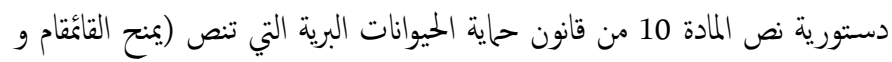

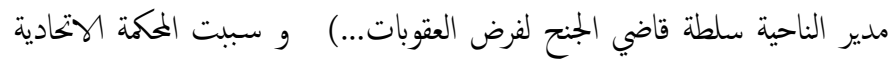

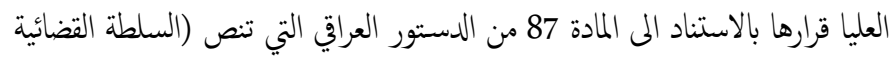

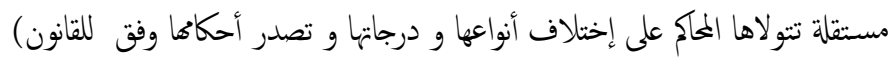

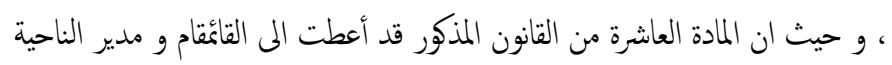

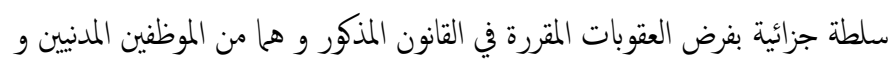

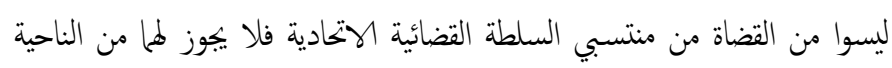

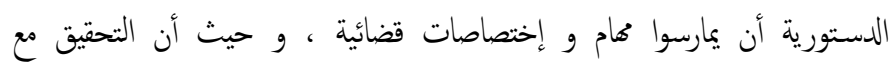

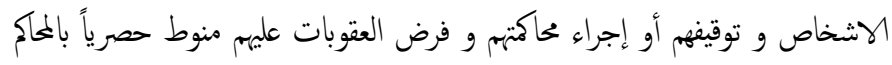

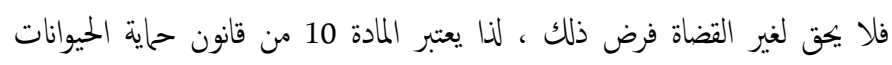

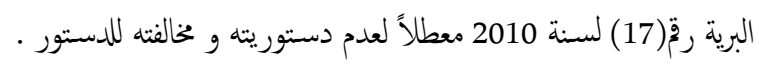
النموذج الرابع/ من المبادئ الدستورية الجنائية في الدستور العراقي عدم رجعية

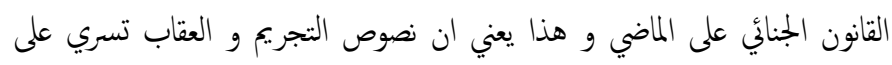

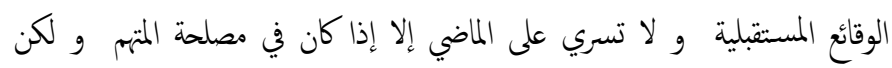

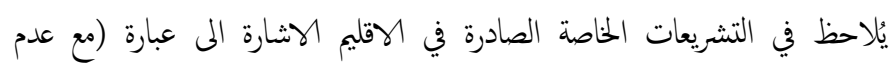

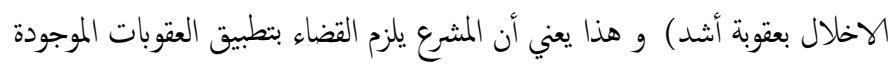

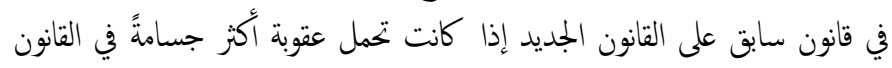

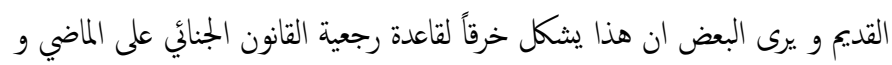

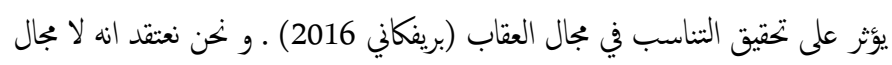

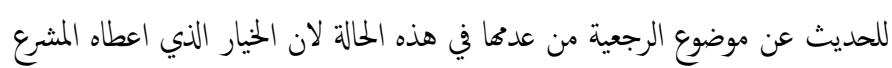

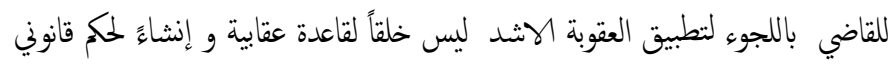
بل ان القول بتطبيق العقوبة الاشد يعني احالة المشرع للقاضي الى قانون موجود أصلاً

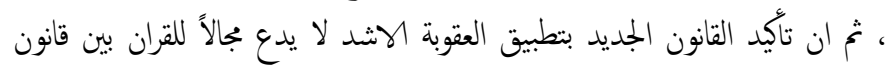

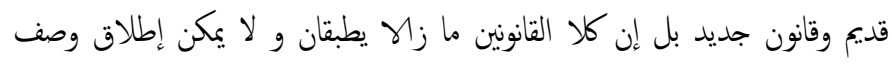

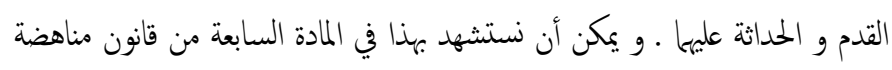
العنف الاسري حيث تنص على عبارة مع عدم الاخلا بعقوبة أثد ، و كذلك المادة

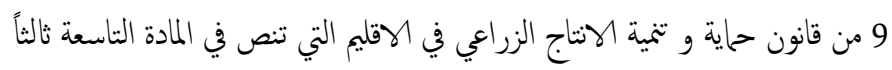

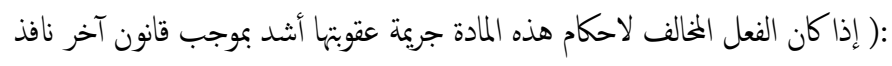

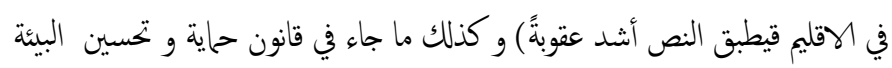

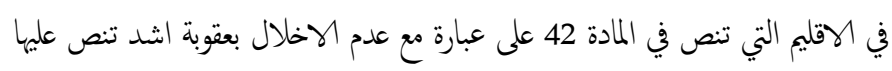

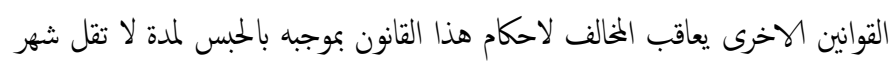

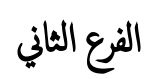

الدستورية في حال إختيارها مواجهة ظاهرة و جعلها مناطاً للتجريم طالما هي لا تخالف

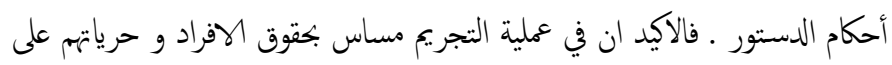

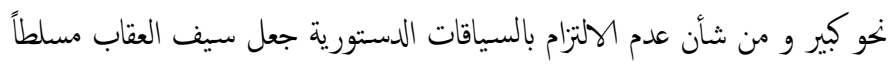

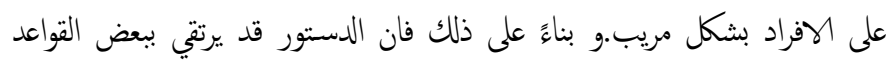

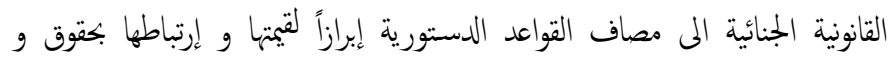

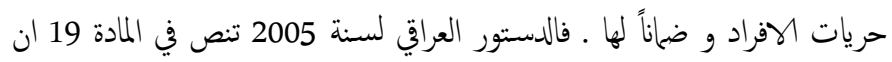

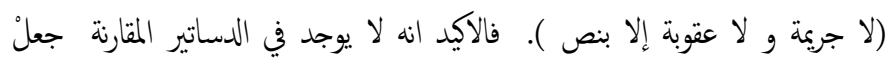

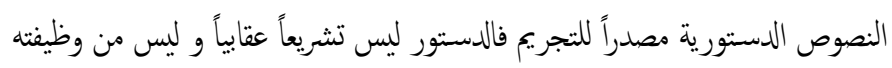

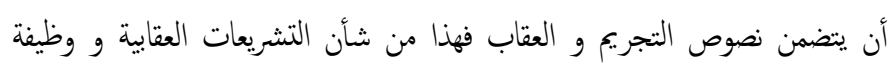

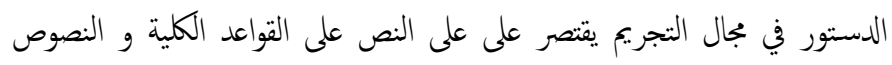
الاصولية التي تضع ضوابط التجريم و العقاب ـو و قد أكد الدستور العراقي هذا المبدأ

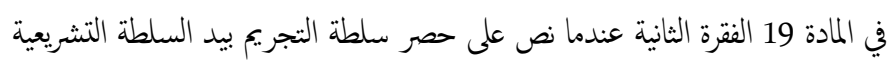

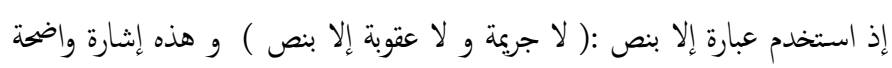

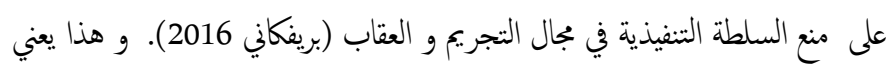

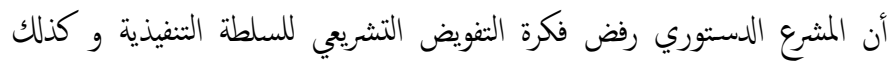

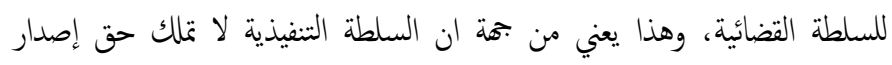

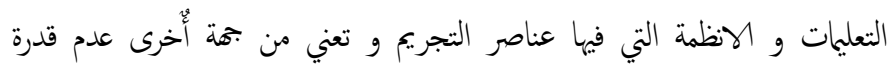

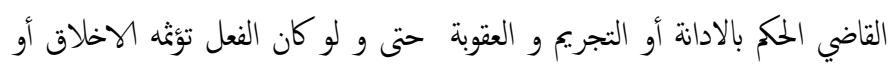

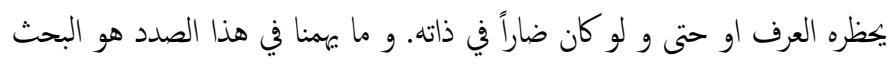

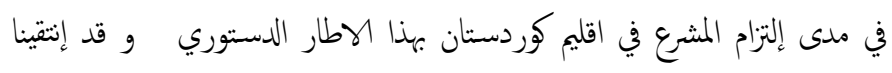

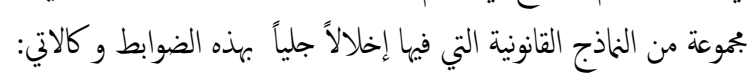

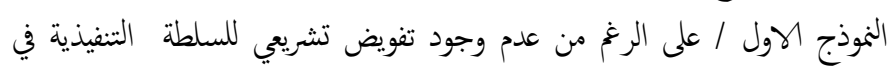

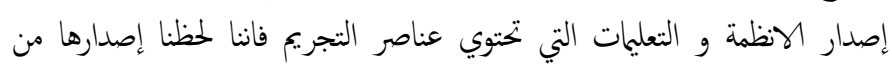

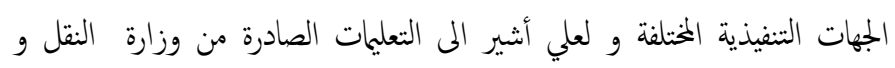

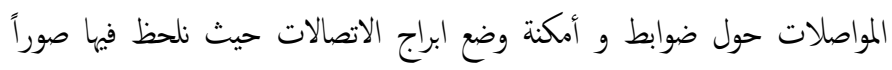

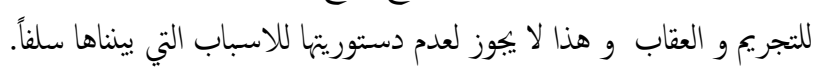

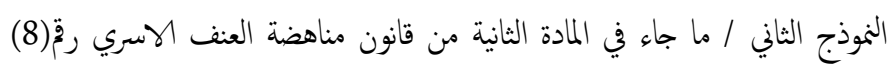

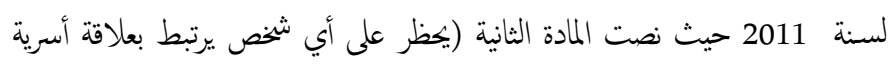

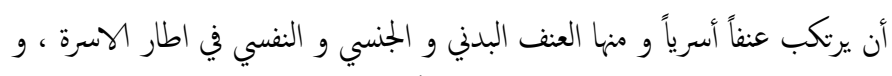

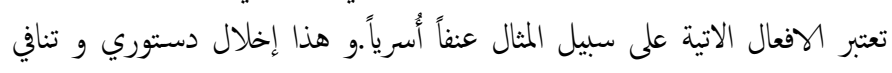

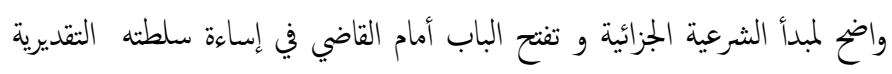

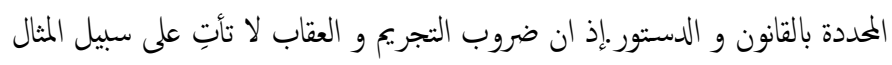
ولا يجوز اللجوء الى القياس في خلق الجرائم.

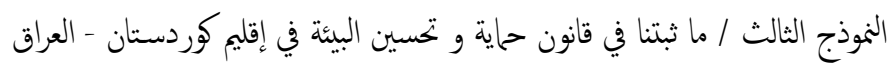

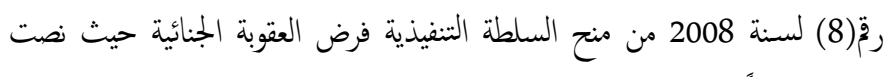

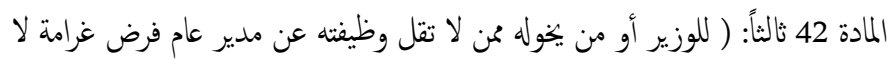
تقل عن (10000) مائة ألف دينار و ولا تزيد عن (10000000) عشرة ملايبن 
و من المظاهر الاخرى لهذا النوع من الاخلال ما استقرئناه من نص المادة الثانية من قانون مناهضة العنف الاسري حيث أبرز المثرع الكوردستاني نطاً إجرامياً سهاه

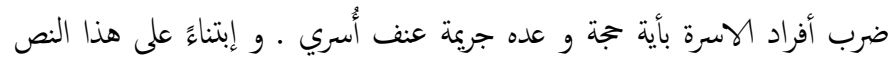

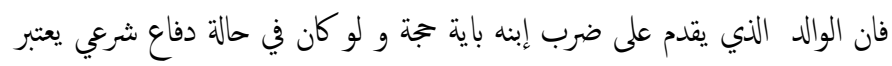

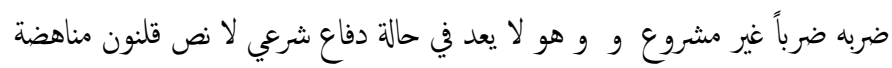

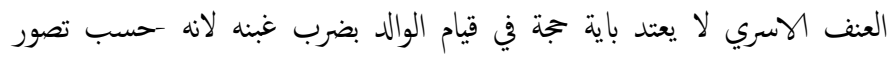

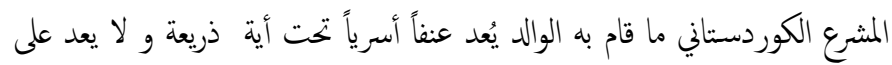

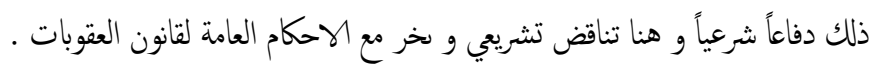

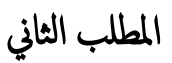

\section{عدم الاعتداد بمعايير الوضوح و اليقين في بناء النوذج القانوني اللجريمة}

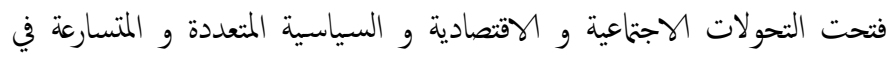

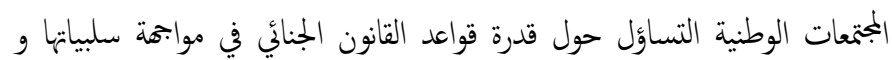

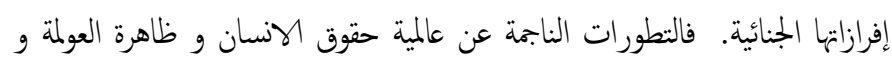

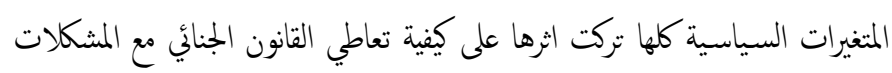

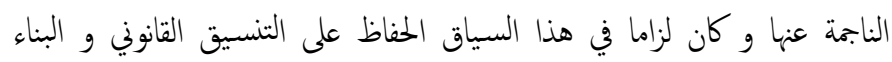

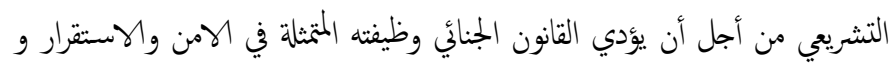

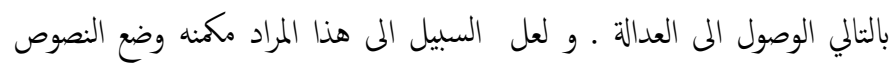

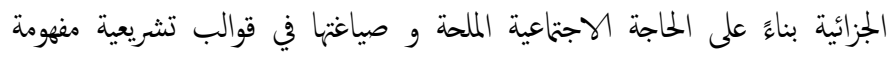

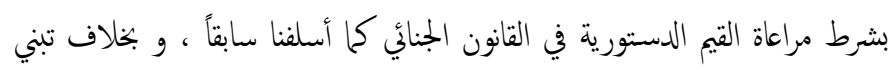

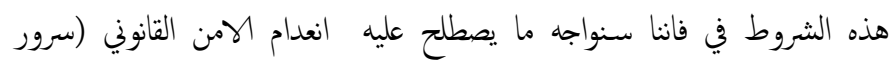

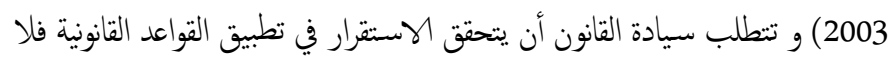

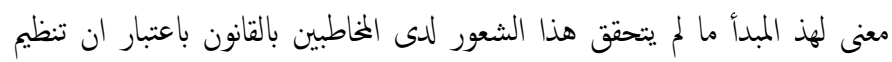

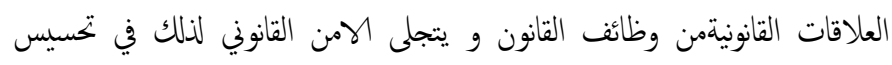

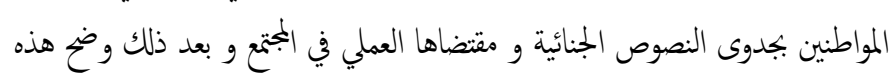

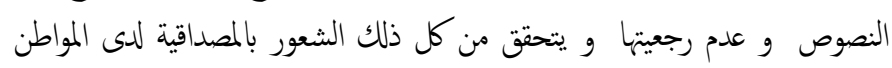

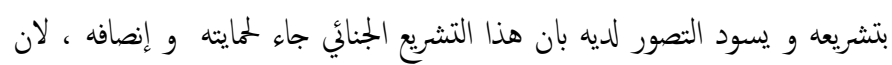

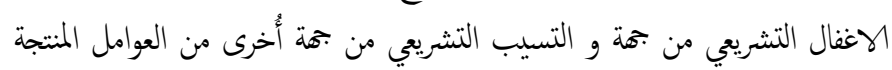

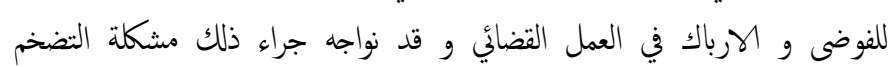

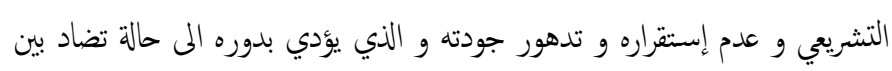

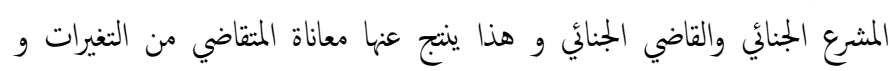

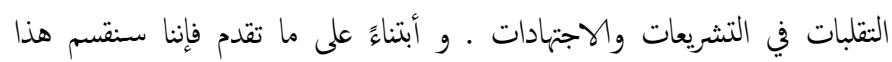

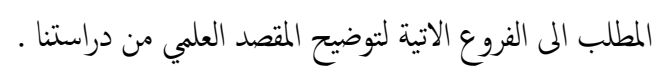

\section{الفرع الاول تعريف اليقين القانوني}

\section{عدم مراعاة الاسس العقابية العامة}

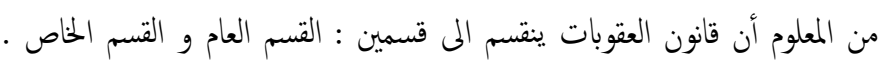

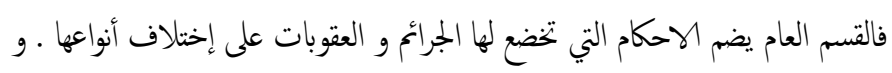

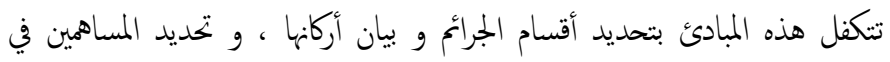

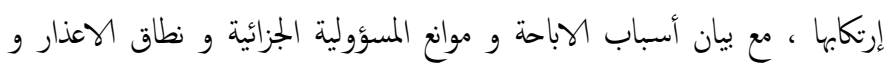

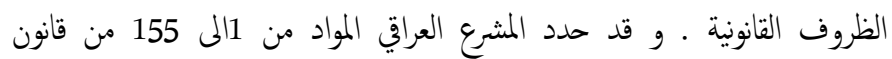

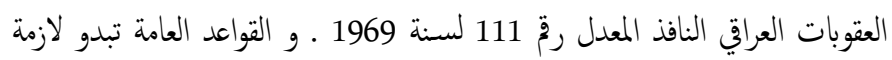

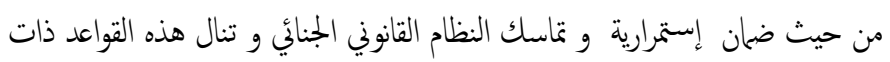

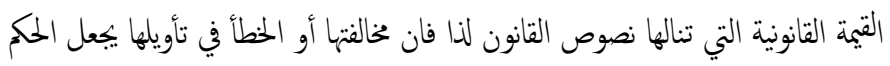

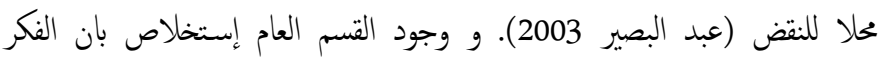

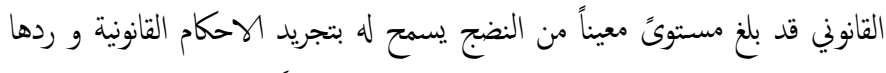

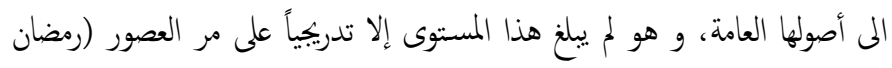

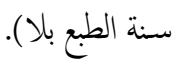
وهذا يقتضي ان لا يخالف القسم الخاص من قانون العقوبات النظرية العامة

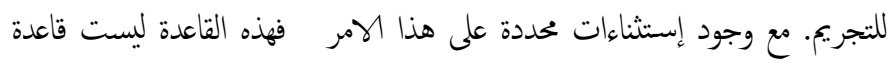

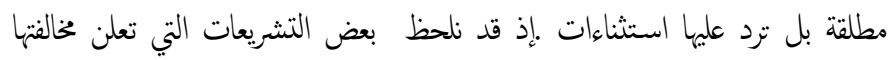

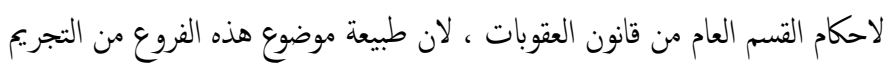

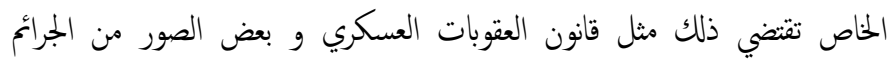
الاقتصادية . الماصن و بعد أستقصاء العديد من التشريعات الجنائية في الاقليم فقد لحظنا خروجاً فير

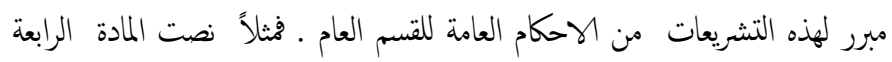

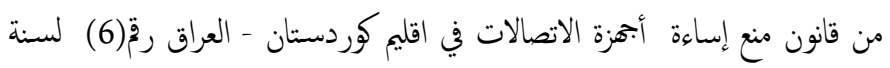
2008 :( إذا نشأ عن الفعل المرتكب وفق المادتين (الثانية ) و (الثالثة) من هذان الثان الثان

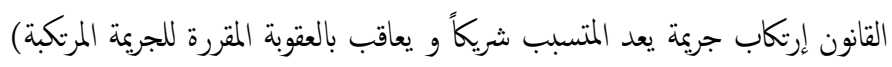

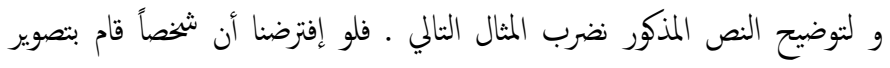

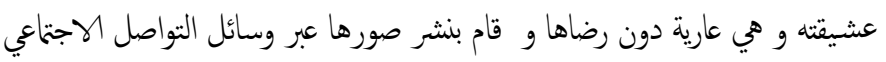

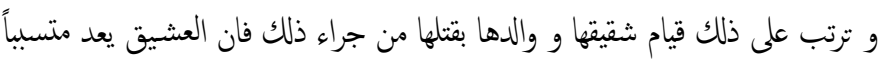

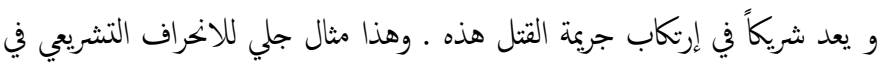

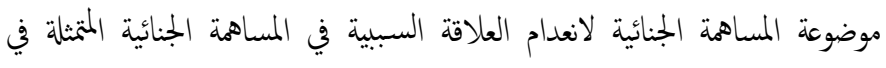

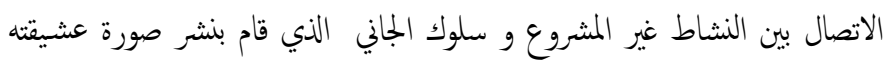

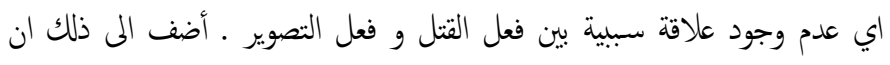

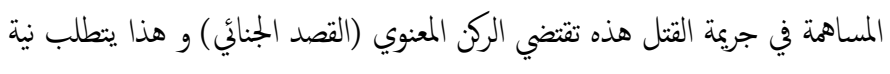

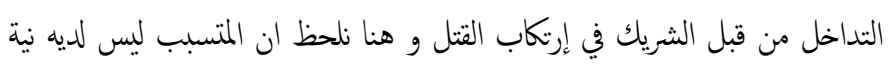

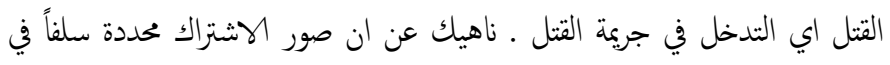

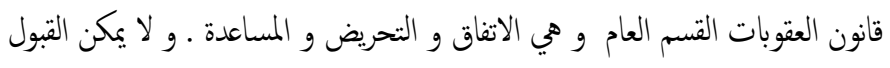

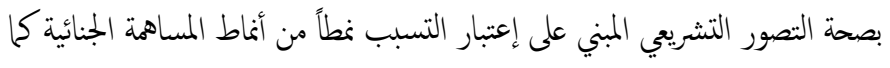

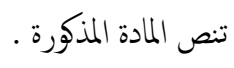


هذا الاسلوب في التجريم الذي يعرف بنص التجريم الاحتياطي من شانه المساس بقرينة البراءة لانه لا يوفر الضمانات التي تتطلها مبدأ الشرعية الجزائية(الممليلي)

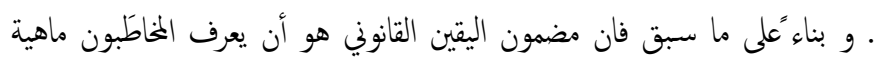

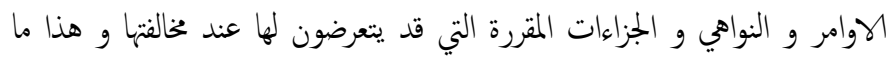
يقتضي صفات خاصة في النصوص الجزائية و في تفسيرها.و لهذا يعد اليقين القانوني

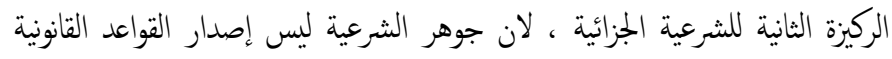

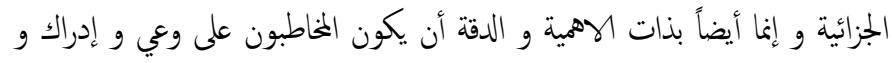

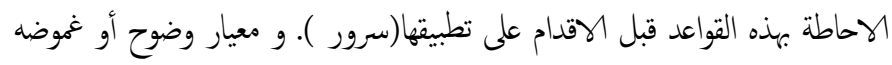
يرتبط بأوساط الناس أي هو معيار الشخص العادي(عبد الله) .

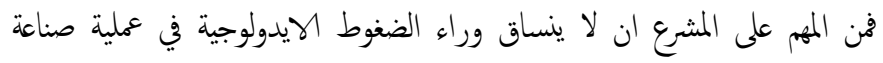

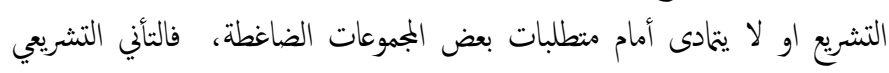

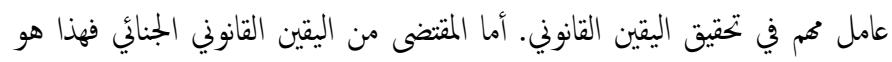

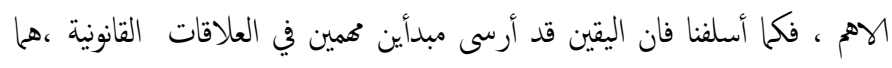

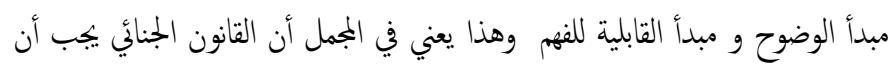

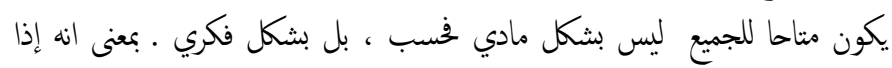

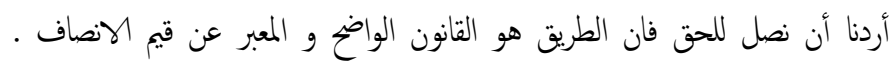

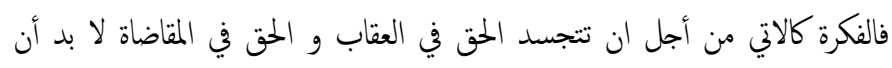
تكون الاجمزة القضائية و العدلية ذات الصلة ملمة بالقوانين، فقعالية الحقوق تبدأ

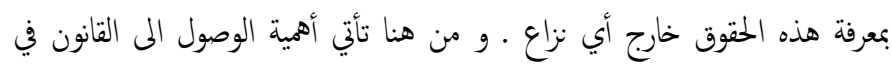

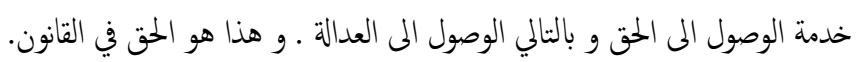

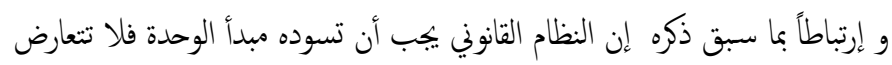

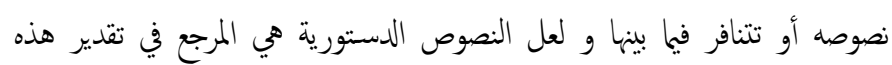

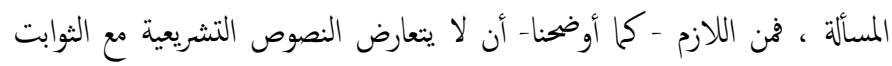

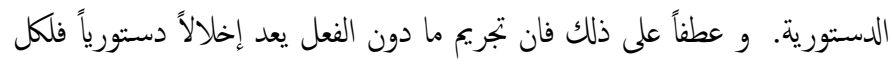

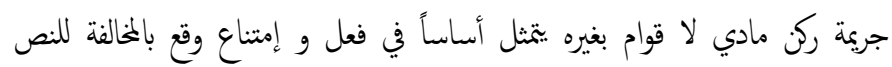

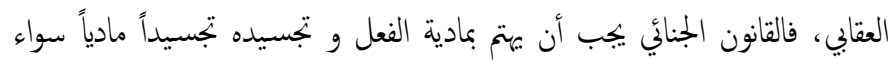

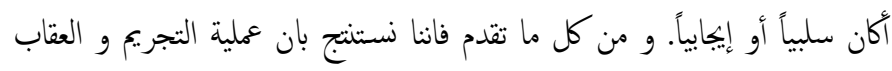

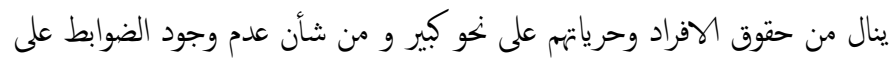

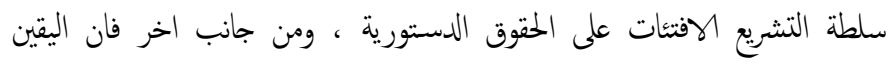

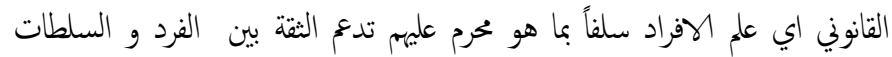

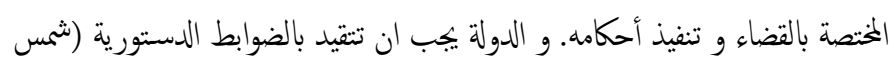

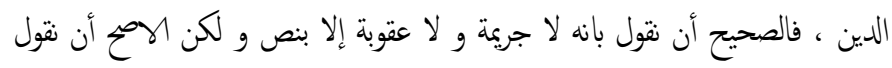

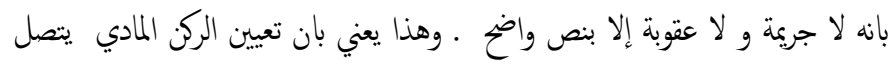

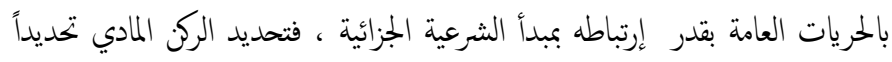

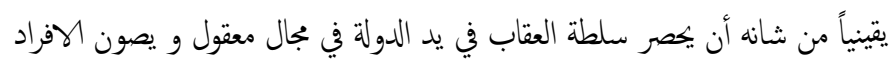

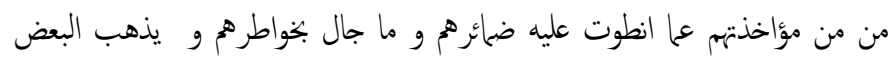

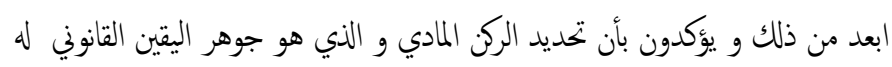

اورد الفقه و القضاء تعريفات متعددة لليقين القانوني، فقد عُرف بانه ضرورة كون

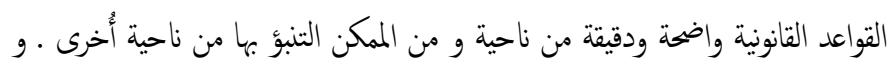

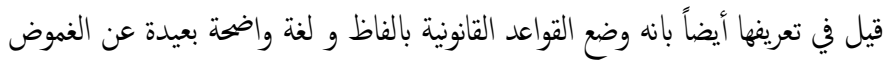

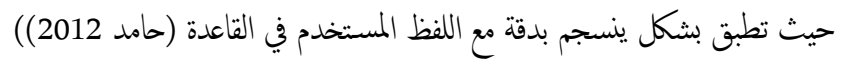

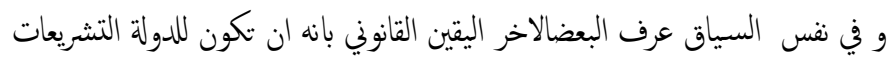

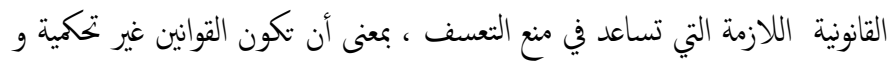

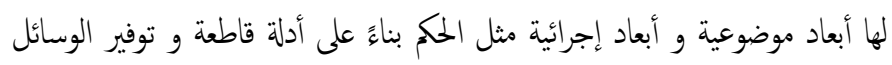

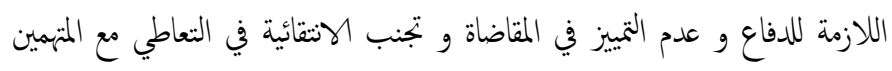

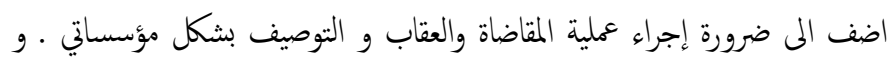
يتجلى من التعريف الاخير بان هناك علاقة وثيقة بين اليقين القانوني و قواعد المحاكة

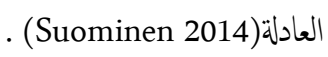
و بنفس المعنى ذهب اخرون بان اليقين القانوني مرده الى ان الخخاطبين بالقانون

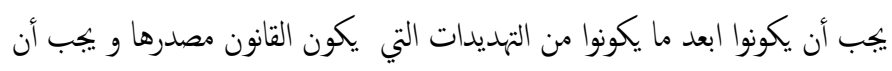
يتم حايتهم من انعدام الامن القانوني الناج من انعدام اليقين( (Safta 2016).

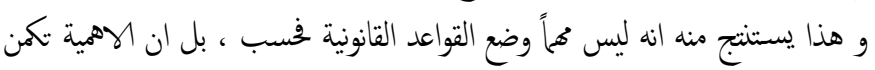

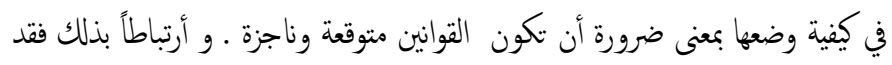

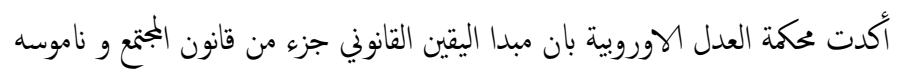

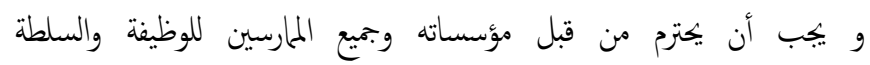
(Maxeinerm.)

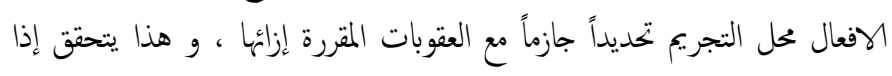

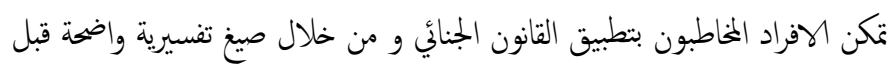

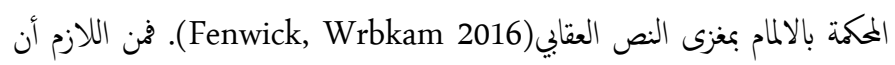

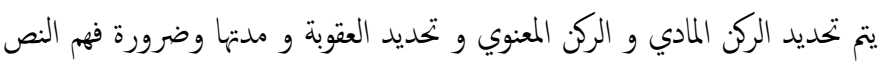

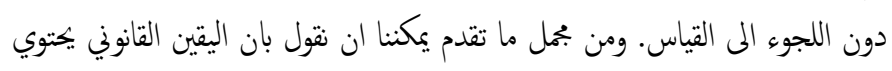

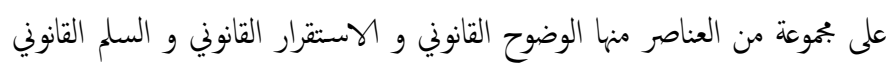
وتوقع تطبيق القانون في ضوء الوستمرارية القانونية و القضائية.

\section{الفرع الثاني مضمون اليقين القانوني الجنائي و مقتضاه}

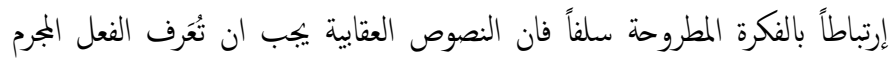

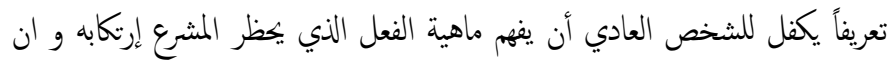

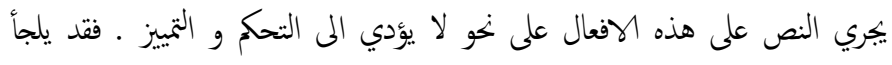

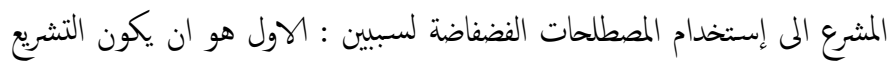

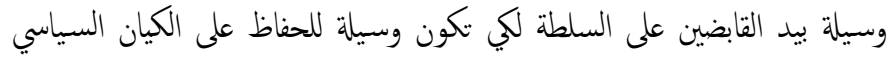

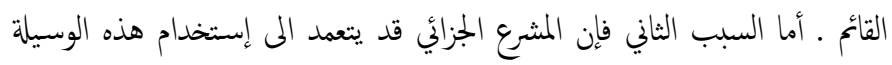

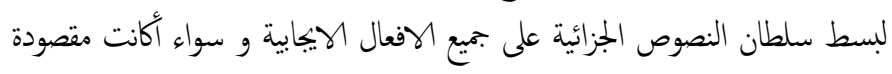

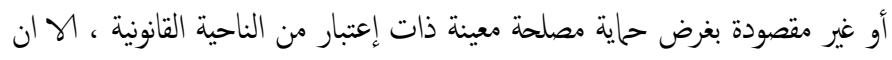


بإمكانا الاستشهاد بعدد غير متناهي من التشريعات الجزائية التي تتصف بالوهن و

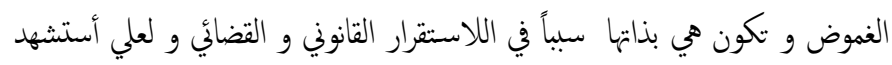

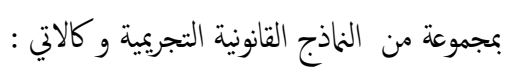

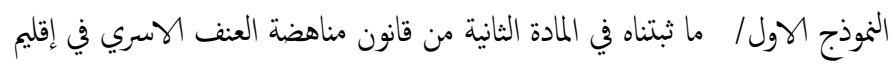

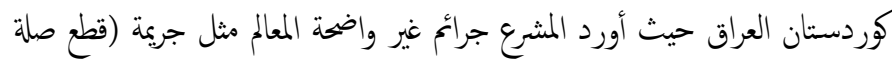

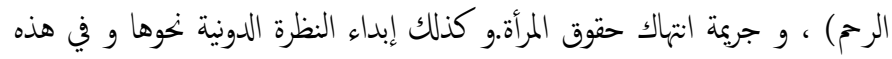

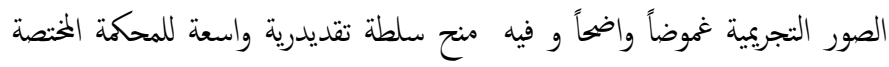

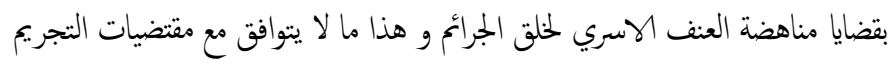

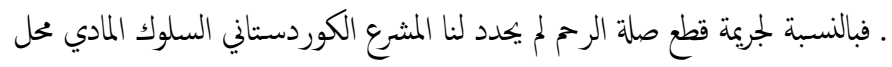

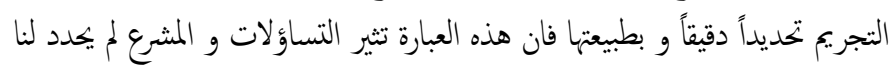

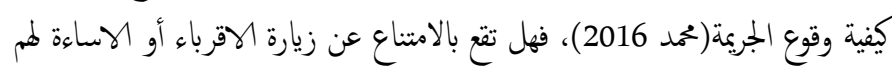

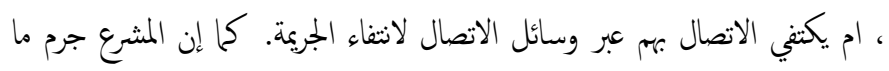

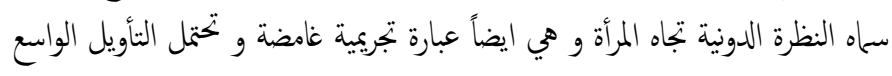

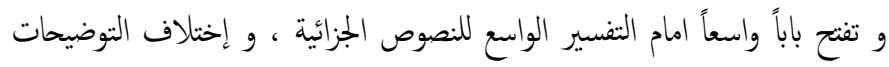

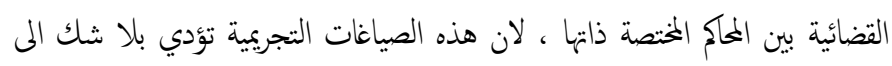

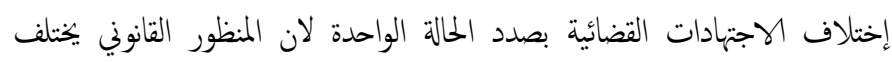

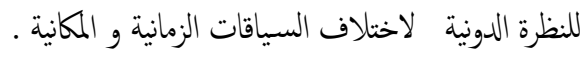

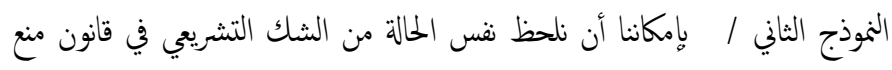

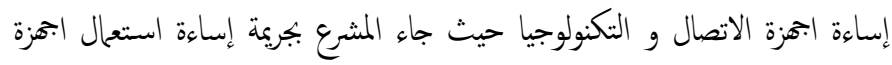

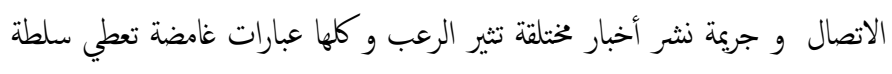
واسعة للقاضي الجنائي في التجريم بشكل لا يتوافق مع شرعية الجريمة و العقوبة.

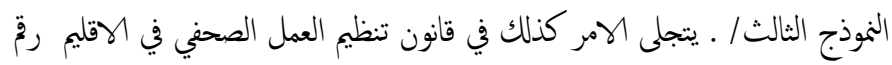

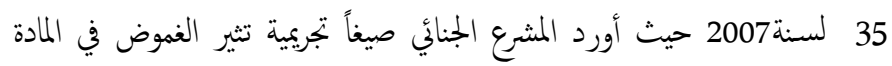

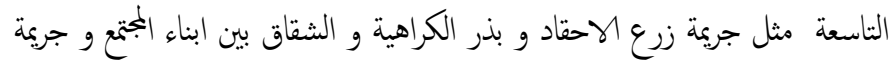

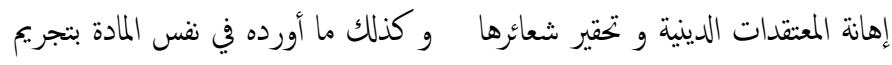

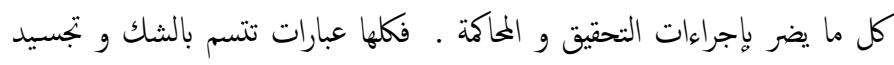
على حقيقة عدم الانضباط التشريعي في النجريم.

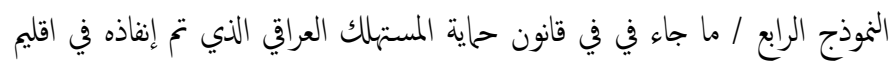

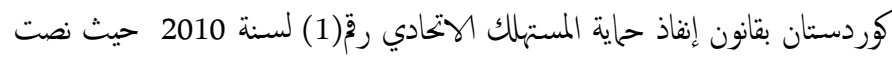

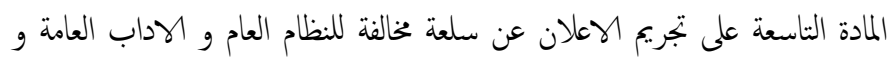

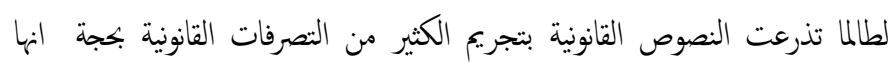

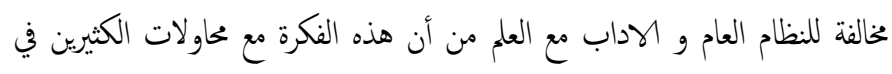

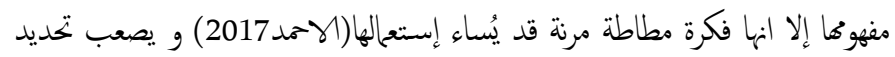
مدلولها و الوقوف على محتواها. النموذج الخامس/ ما جاءت في المادة الاولى من القانون رقّ 42 لسنة 2004 التي

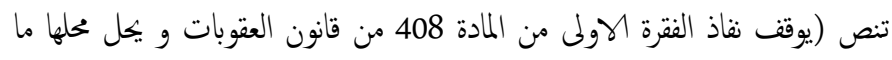

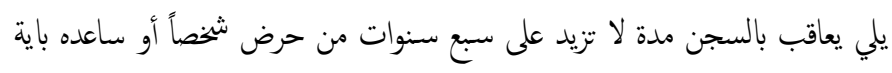

مبرر سياسي فالافكار الاخلية للانسان من الصعب النعرف علها فكثيراً ما يسيء

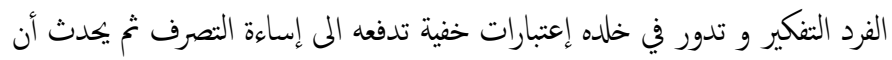

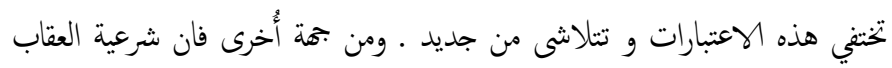

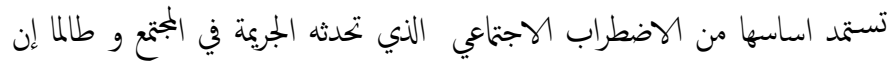

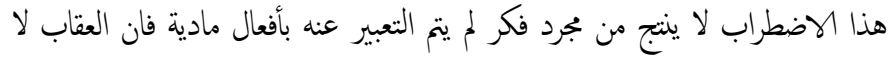

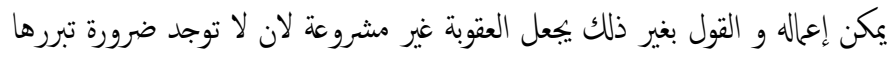

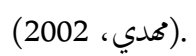
• و هذ يؤدي بنا الى القول بان القاضي الجنائي عندما يواجه واقعة معينة و نصوص

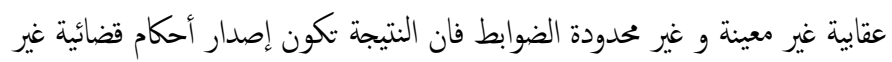
موفقة ـ و عليه فان التزام المشرع بالوضوح و البيان يُعد نتيجة من نتائج الشرعية

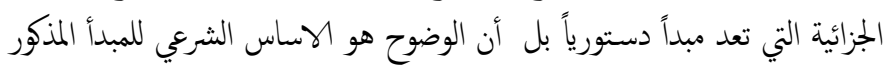
(البجالي ، 1998). و لا مراء من القول بان اليقين القانوني قد يجد له تأصيلا دستورياً من زاوية أُخرى و

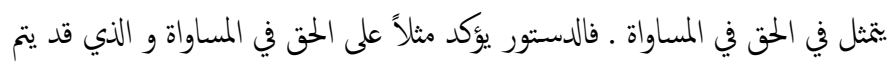

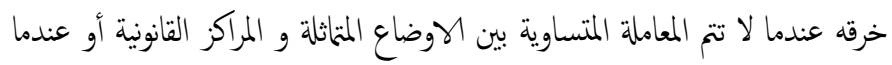

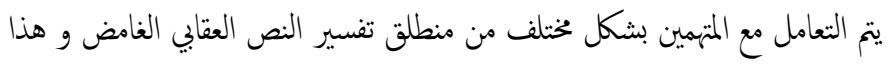

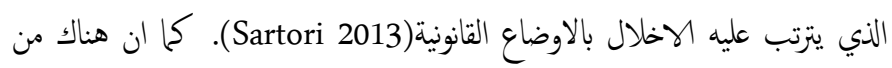

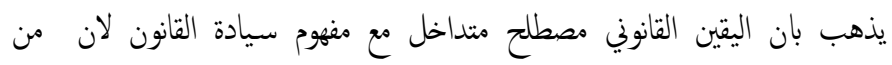

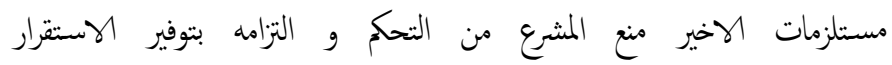

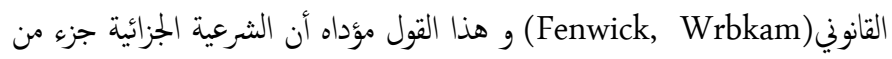

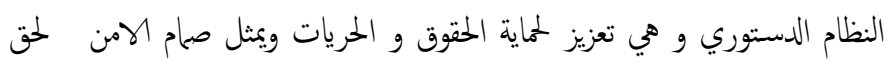
مقدس من حقوق الانسان و هو الحرية الشخصية، و هذا ثابت في الدستور العراقي

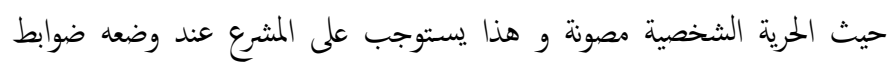

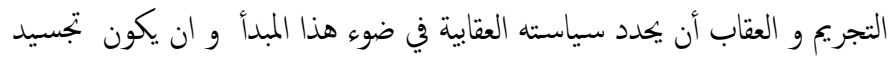

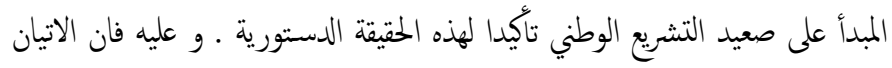

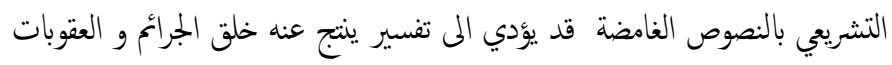
و هذا القول يُستنتج منه منطقيا السياق الدستوري لليقين القانوني الجزائي.

\section{الفرع الثالث}

\section{مظاهر الاخلال باليقين القانوني في التشريعات الجنائية}

لقد اصبحت التنريعات الجنائية الغامضة سمة من سمات العمل التشريعي في العراق و في الاقليم و يرتبط هذا الموضوع بموضوع (النموذج القانوني) فالقاعدة القانونية الجنائية

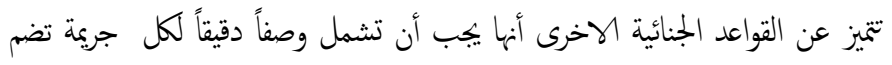

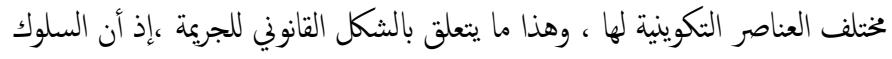

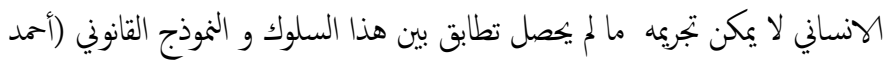


1- إن المغزى العلمي من هذه الدراسة كان بيان مظاهر الانحراف في التشريعات الجنائية في إقليم كوردستان العراق لعدم تضمينها الشروط الموضوعية و الشكلية الواجب توافرها في التشريعات الجنائية و و قصدنا بالانحراف البناء التشريعي الجنائي

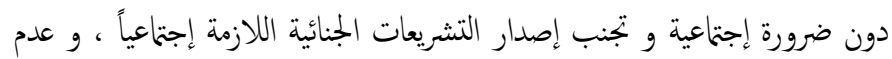

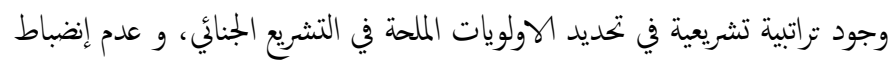
العبارات التي تُصاغ فيها القوالب التشريعية الجنائية الخاصة بالتجرئيك.

2- تجنبأ للانحراف و عطفاً على عدم خروج التشريع الجنائي عن مسار الحل

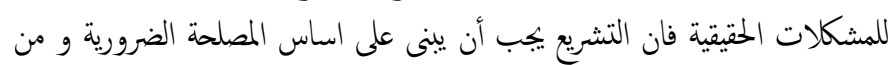

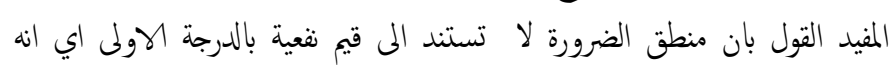

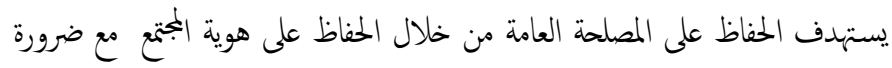

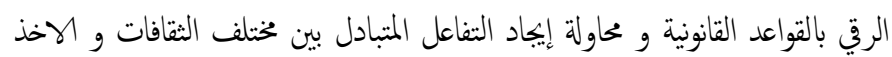

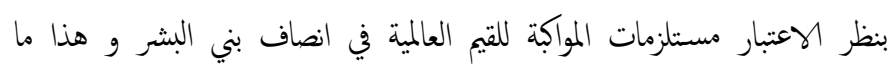

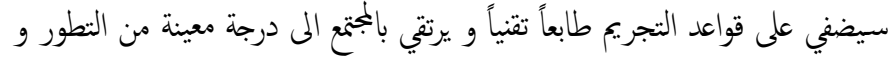

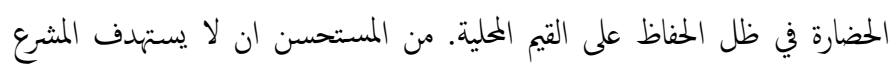

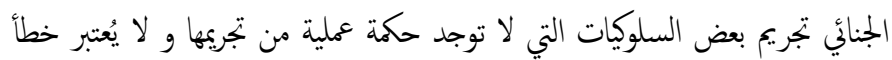

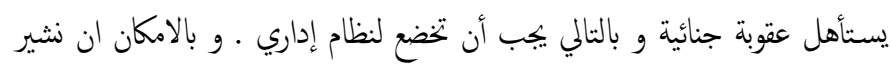

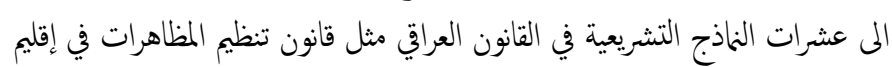
كوردستان المرقٍ 11 لسنة 2010 و قانون مكافة التدخين في إقليم كوردستان

3- من المنطقي ان التثريع يبدأ بخاطرة بامكانا أن نسميه الخاطرة التشريعية الجنائية

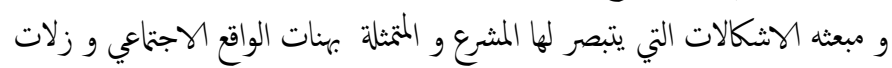

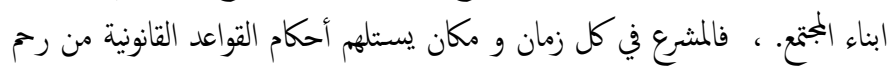

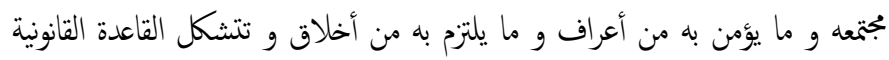

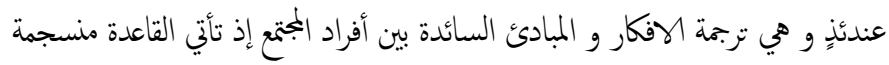

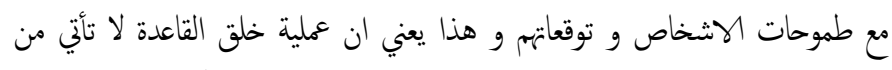

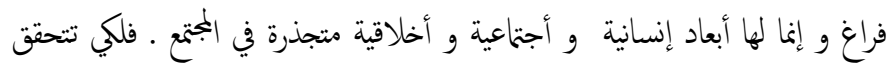

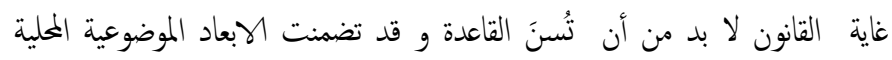

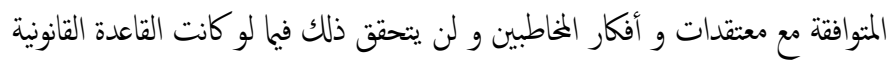

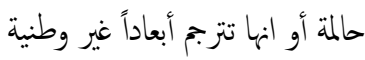
4- - حاول المشرع الكوردستاني - إرتباطاً بالتوظيف السياسي اللتشريعات الجنائية-

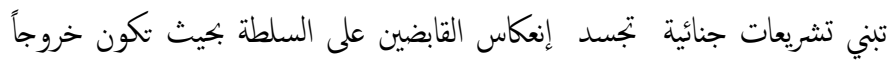

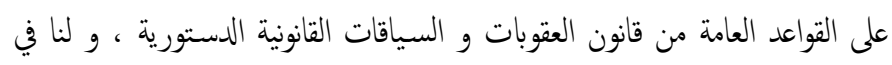

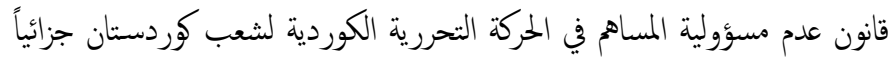

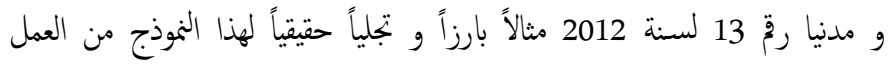

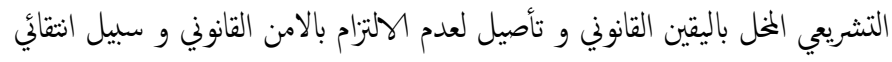

وسيلة أو تسبب فيه إذا ما تم الانتحار بناءً على ذلك) و المشرع هنا خلق جريمة

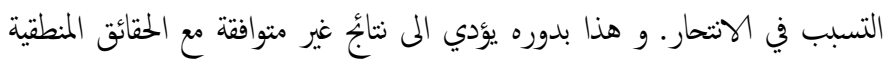

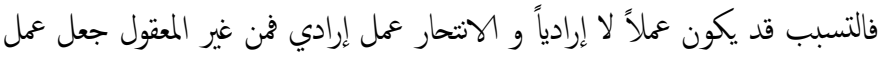

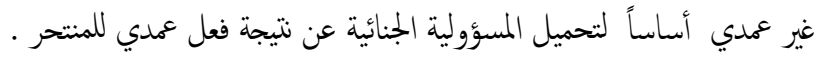

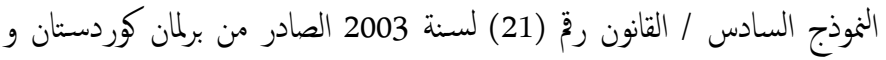
القاضي وايقاف العمل بالمادة 156 من قانون العقوبات و إحلال المادة التالية محلها: (

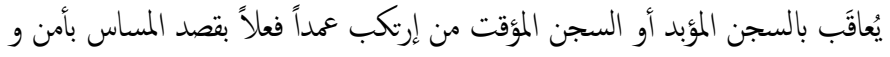

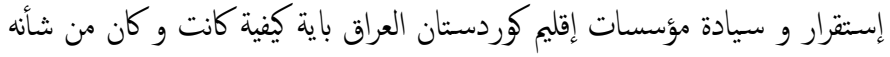

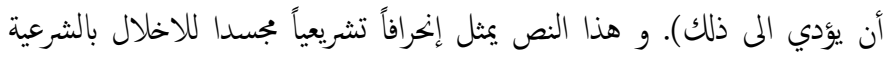

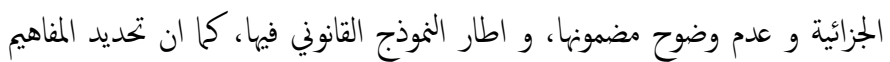

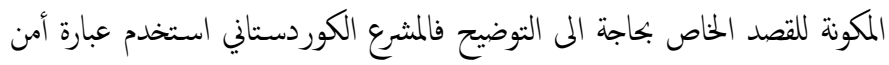

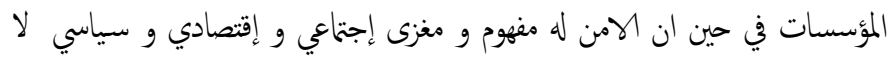

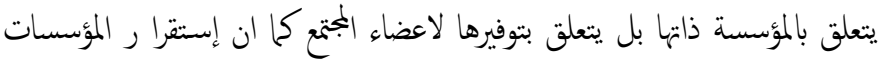

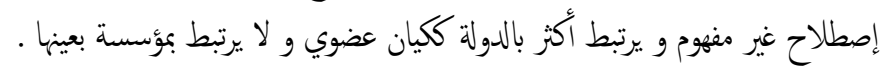

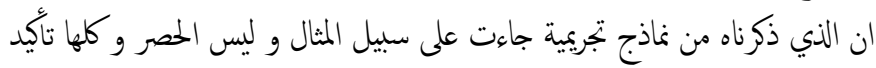

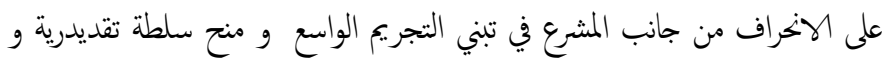

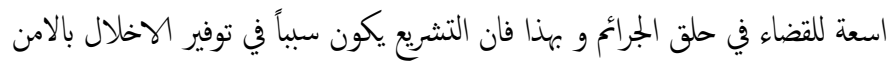

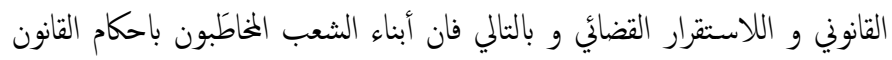

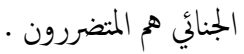

\section{الخامة}

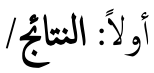


4- إرتباطاً بحتيقة علمية وقانونية مفادها أن التشريعات الجنائية ليست حيزاً للمناكفات

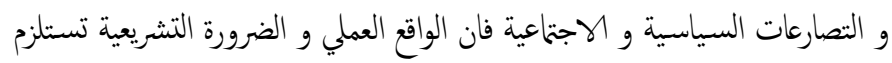

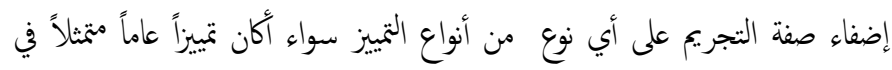

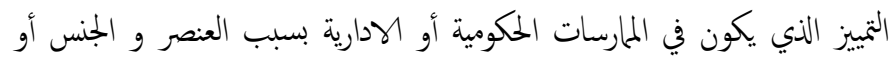

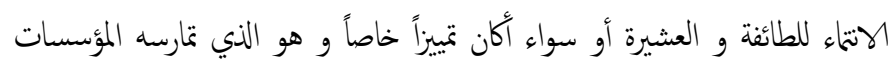

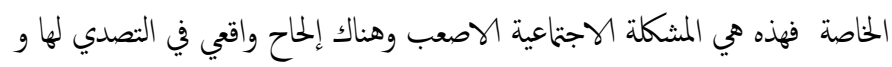
تحريما و تجريما و من خلال ذلك في بالامكان تبني التشريعات السلمة التي تنتصر

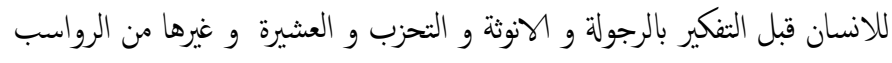

. الاجتماعية

5- لقد اصبح ضرورة تقنين الجريمة الدولية على الصعيد التشريع الجنائي الوطني قاعدة

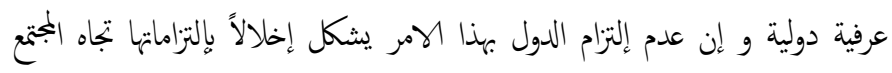

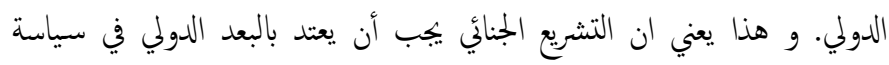

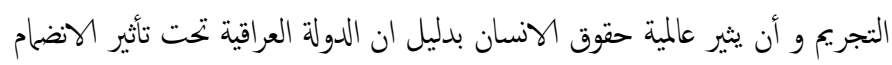

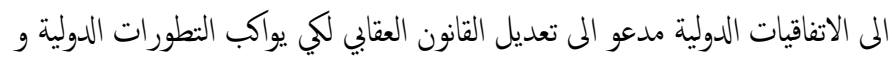
يحقق الالتزامات الدولية.و عليه فان المتضضى تستطلب تقنين الجرائم الدولية و الجرائم

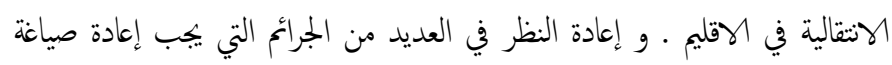

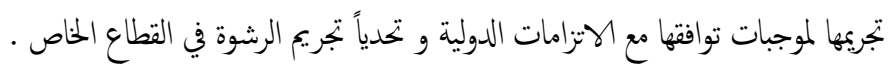

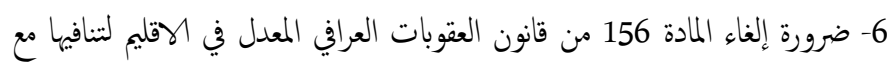
الشرعية الجزائية و مقتضيات الامن و اليقين القانوني .
5- إقتنعنا من خلال هذه الدراسة إن جزءً من موضوعة الانحراف و خروج التشريع

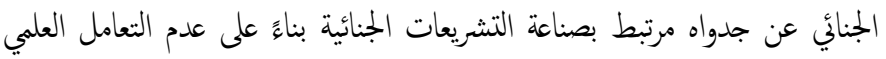

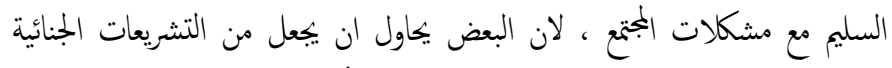

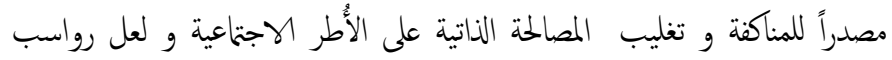

التميز بين المرأة و الرجل على مدار القرون أوصلنا الى هذا الهارباك التشئ التشريعي.

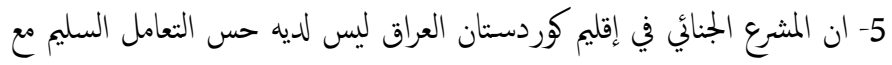

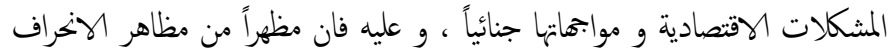

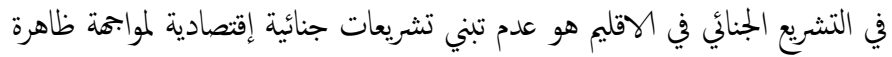

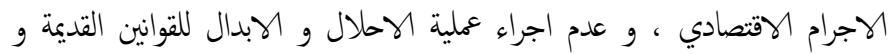
تطويرها لكي تكون مواكبة للتطورات الاقتصادية الناجة عن ظاهرة العولمة .

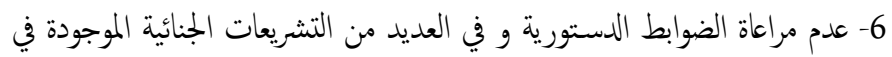

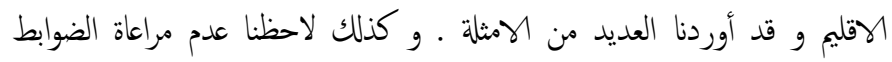

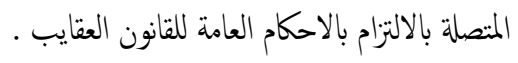

\section{ثانيآ/ الاقتراحات}

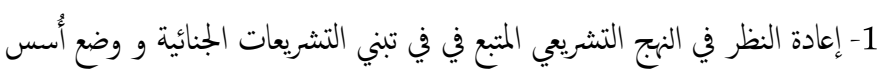

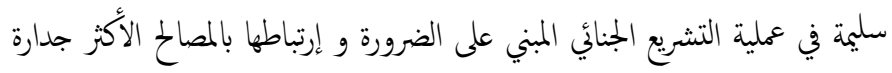

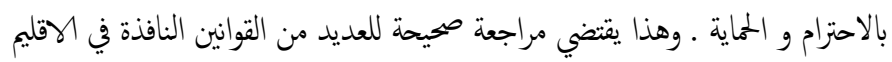
و نذكر على سبيل المثال قانون مناهضة العنف الاسري و قانون تنظيم العمل الصحني و قانون تعديل تطبيق قانون العقوبات العراقي رخ (3) لسنة 2015.

2- ضرورة أخذ المشرع الجنائي منظومة القيم في المجتع و هذا يعني أن المشرع مدعو

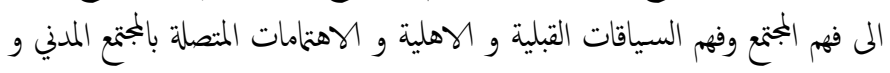

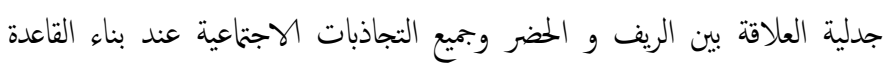

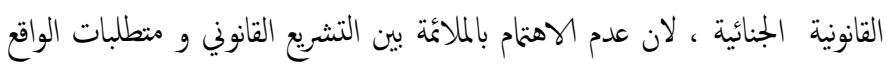

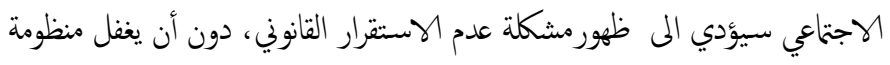

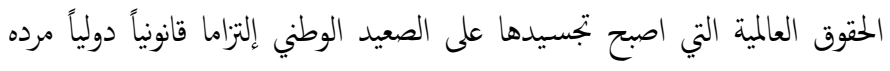

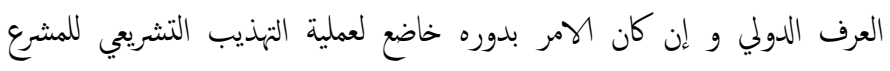

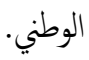

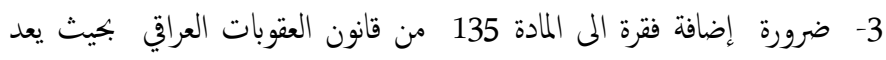

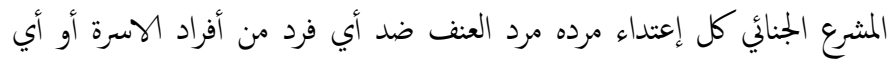

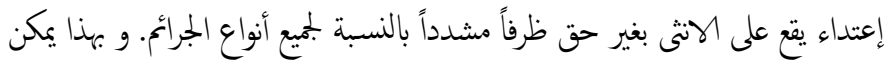
المصادر

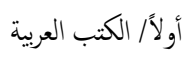

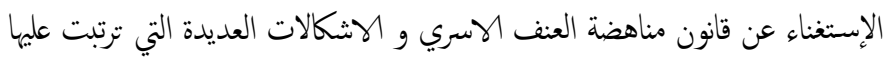
و كذلك يقتضي الامر إلغاء قانون تعديل تطبيق قانون العقوبات العراقي في إقليم

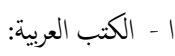


21- البريفكني. دلشاد عبد الرهن. (2016) ، مبدأ التناسب في القانون الجنائي ، دراسة مقارنة

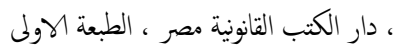

22- دالمهيلي. عبد الجبار رشيد. (2015) ، عولمة القانون الجنائي الدولي و أثرها في حفظ الامن

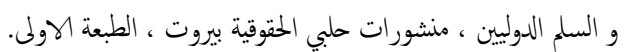

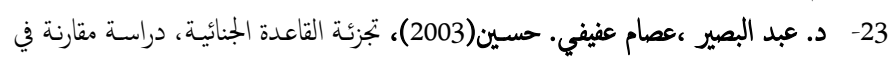

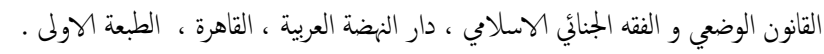

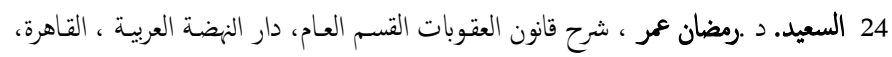

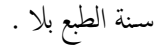

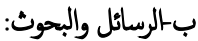

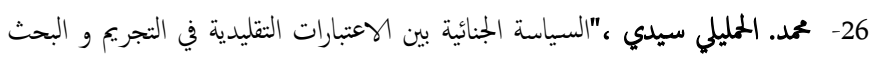

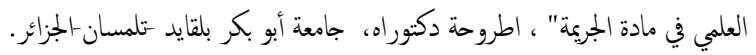

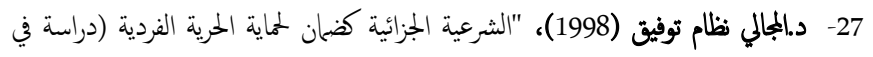

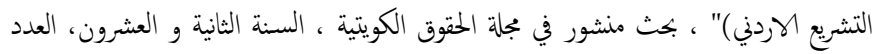

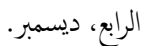
28- د.دلفوف. جال الدين. (2014) ، "مبدا التناسبية في قانون العقوبات" ، مذكرة لنيل شهادة الماجستير في القانون العام -فرع القانون الجنائي جامعة بسكرة الجزائر.

29- د الجادر. تميم طاهر ، سيف صالح. (2013) ، "الضرورة و التناسب في القاعدة الجنائية" ، مجلة السياسة الدولية ، الجامعة المستنصرية سنة.

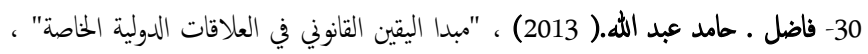

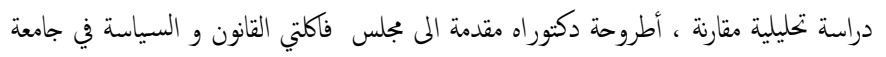

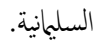
31- عبد الرزاق. السعيدي عباس. (2016)، "ضوابط استحداث النص الجزائي الخاص" ،رسالة ماجستير مقدمة الى مجلس فاكلتي القانون - جامعة سوران.

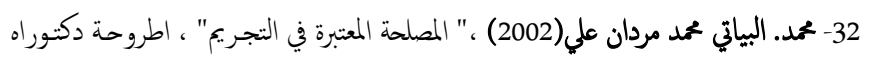
مقدمة الم مجلس كلية القانون جامعة الموصل.

33- علي. د.عيسى بسين عبد. (2016) ، "إصلاح قانون العقوبات و مستلزمات إقامة الحميك

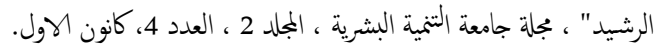

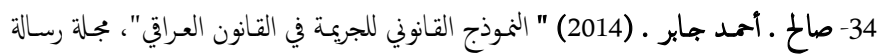
الحقوق، السنة السادسة ، العدد الاول.

35- محمد ـ شـيلان سلام ، "المعالجة الجنائية للعنف ضـد المرأة في نطاق الاسرة"، رسالة

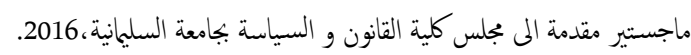

$$
\begin{aligned}
& \text { ج- الدساتير و القوانين } \\
& \text { 1- الدستور العراقي لسنة } 2005
\end{aligned}
$$$$
\text { 2- قانون العقوبات العراقي المرة } 111 \text { لسنة المبنة } 1969
$$

3- القانون رقّ 21 لسنة 2003 المتعقق بايقاف العمل بالمادة 156 من قانون العقوبات

$$
\text { العراقي }
$$

4- القانون رق(42) لسنة 2004 (ايقاف نفاذ الفقرة (1) من المادة 408 من قانون العقوبات

$$
\text { العراقي رق } 111 \text { المعدل }
$$

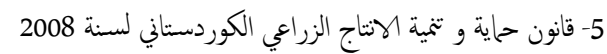

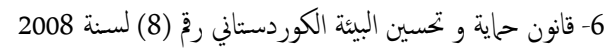
7- قانون منع إساءة اجهزة الاتصالات رقز (6) لسنة 2008
1. فتحي • د سرور أحمد (2000) المحاية الدستورية للحقوق والحريات ، دار الثروق ، القاهرة .2b،

2. فتحي. الدكورسرور أهمد ، القانون الجنائي الدستوري، دار الشروق ، القاهرة ، مصر،

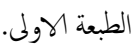

3. فاضل ـ عامد عبد الله. (2013)، مبدا اليقين القانوني في العلاقات الدولية الخاصة ، دراسة

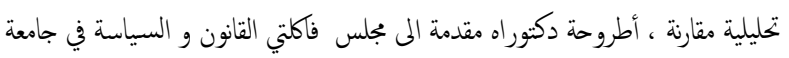
السليمانة. 4 الدكتور شمس الدين، توفيق. أشرف (2014)، شرح قانون العقوبات القسم العام، النظرية العامة للجريمة، دار النهة العربية، القاهرة،الطبعة الثالثة. 5- مهدي ، عبد الروف. (2011) شرح القواعد العامة للقانون العقوبات، دار النهضة العربية ،

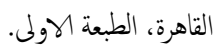
6- سليان. د. الاممد محمد. (2017)، فلسفة الحق، منشورات زين الحقوقية ، لبنان.

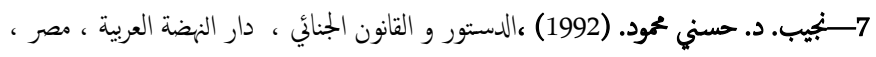

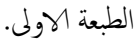

8- علي. دالشتا السيد. (1997) ،علم الاجتماع الجنائي، مكتبة الاشعاع للطباعة و النشر و الطباع

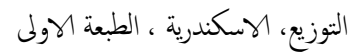

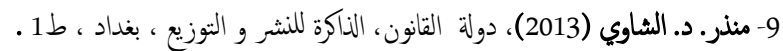

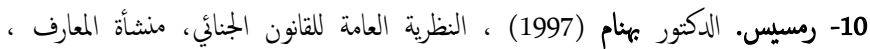

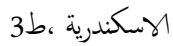
11- د. الهيتي، نصار. محروس (2011)، النظرية العامة للجرائم الاجتاعية منشورات زين الحقوقية ، لبنان ، كلائي،

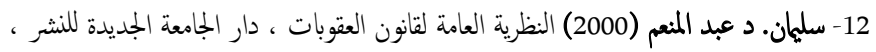

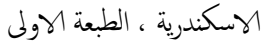

13 - دحمة كميم • زانا رؤوف.(2012) ، السياسة التشريعية في العراق ، دراسة تطبيقية في

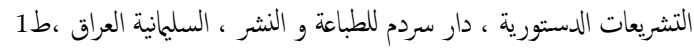

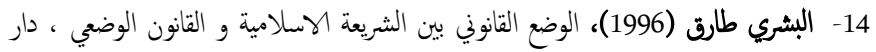

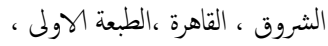

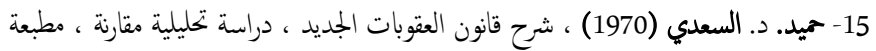

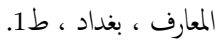
15- د عبد الثافي. وائل حسن (2009) ، مشكة النصص في القانون بين المذاهب الفلسفية و

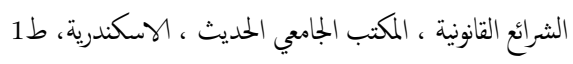

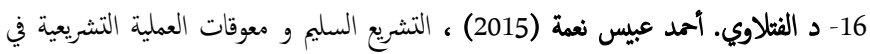

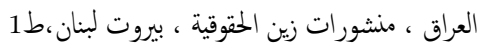

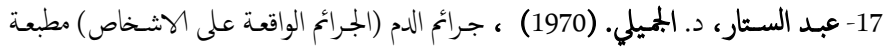
الارشاد ،بغداد ، الطبعة الاولى ، ص د 395

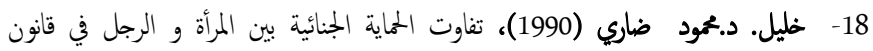

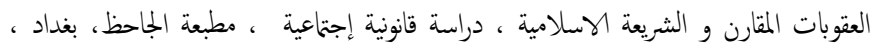

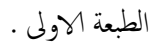
19- د. جال فاسمية .( 2013)، منع التميز في القانون الدولي لحقوق الانسان و آثاره، دار الجامعة

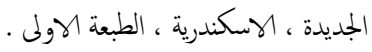
20 أبو بكر. عمر رييين. (2017) ، السياسة الجنائية في الجرائم الاقتصادية، دراسة تحليلية

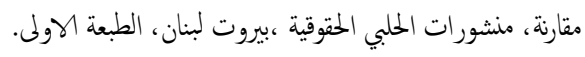


Maxeiner, J. R. (2010). Some Realism About Legal Certainty in the Globalization of the Rule of Law. In The Rule of Law in Comparative Perspective (pp. 41-55). Springer, Dordrecht.

Fenwick, M., \& Wrbka, S. (Eds.). (2016). Legal Certainty in a Contemporary Context: Private and Criminal Law Perspectives. Springer.

Sartori, D. (2014). The lex certa principle. From the Italian Constitution to the European Convention on Human Rights(Doctoral dissertation, University of Trento).

Sartori, D. (2014). The lex certa principle. From the Italian Constitution to the European Convention on Human Rights(Doctoral dissertation, University of Trento).

Boister, N. (2012). An introduction to transnational criminal law. Oxford University Press.

$$
\begin{aligned}
& \text { 8- قانون إنفاذ قانون حاية المستهلك الاتحادي رقة } 9 \text { لسنة } 2010 \\
& \text { 9- قانون مناهضة العنف الاسري رقة } 8 \text { لسنة } 2011 \\
& \text { 10- قانون تعديل تطبيق قانون العقوبات العراقي رث } 3 \text { لسنة } 2015 \text { الكوردستاني . } \\
& \text { ثانياً/ المصادر باللغة الكنكليزية }
\end{aligned}
$$

Suominen, A. E. (2014). What Role for Legal Certainty in Criminal Law Within the Area of Freedom, Security and Justice in the EU? Bergen Journal of Criminal Law \& Criminal Justice, 2(1), $1-31$.

Predescu, I., \& Safta, M. (2016). The Principle of legal certainty, basis for the rule of law landmark case-law. 